\title{
Molecular strategies for detecting chromosomal translocations in soft tissue tumors (Review)
}

\author{
MARGHERITA CERRONE, MONICA CANTILE, FRANCESCA COLLINA, LAURA MARRA, \\ GIUSEPPINA LIGUORI, RENATO FRANCO, ANNAROSARIA DE CHIARA and GERARDO BOTTI \\ Pathology Unit, INT Pascale Foundation, I-80131 Naples, Italy
}

Received December 5, 2013; Accepted January 29, 2014

DOI: $10.3892 /$ ijmm.2014.1726

\begin{abstract}
Approximately one third of soft tissue tumors are characterized by chromosomal aberrations, in particular, translocations and amplifications, which appear to be highly specific. The identification of fusion transcripts not only supports the diagnosis, but provides the basis for the development of novel therapeutic strategies aimed at blocking the aberrant activity of chimeric proteins. Molecular biology, and in particular, cytogenetic and qualitative and quantitative polymerase chain reaction technologies, allow with high efficiency and specificity, the determination of specific fusion transcripts resulting from chromosomal translocations, as well as the analysis of gene amplifications. In this review, various molecular techniques that allow the identification of translocations and consequent fusion transcripts generated are discussed in the broad spectrum of soft tissue tumors.
\end{abstract}

\section{Contents}

1. Introduction

2. Adipocytic tumors

3. Fibroblastic/myofibroblastic tumors

4. Skeletal muscle tumors

5. Tumors of uncertain differentiation

6. Ewing's sarcoma

7. Conclusion

\section{Introduction}

Soft tissue sarcomas are a complex group of rare mesenchymal lesions, many of which are distinguishable from the others only through careful histological and ultramicroscopic investigations. Their diagnosis is problematic due to their rarity;

Correspondence to: Dr Monica Cantile, Pathology Unit, INT Pascale Foundation, via M. Semmola, I-80131 Naples, Italy

E-mail: monicantile@libero.it

Key words: soft tissue tumors, chromosomal translocations, molecular analyses
$15-20 \%$ of these sarcomas are poorly differentiated, with a wide cellular variety that makes their classification difficult. In addition, histological subtypes which are morphologically similar present cytogenetic and molecular differences that influence the prognosis.

Sarcomas are generally classified on the basis of tumor cell line differentiation rather than on the type of tissue from which they arise. A number of histotypes of differentiated tumor cells have been identified: adipocyte differentiation, fibroblast/ myofibroblast differentiation, fibrohistiocytic differentiation, smooth/skeletal muscle differentation, tumors of uncertain differentation and a separate group which includes Ewing's sarcoma (ES). However, not all histological types described present specific chromosomal alterations. For this reason, they are often grouped into 'sarcomas with specific genetic alterations' and 'sarcomas with no specific genetic alterations' (Fig. 1). In pleomorphic sarcomas, only cytogenetic and molecular biology allow a correct diagnosis, identifying specific chromosomal and molecular rearrangements (1).

Thus, the combination of morphological and molecular techniques represents an important progress, not only for a more adequate diagnostic definition, but also for the prognostic and therapeutic indications of these malignancies. Comparative genomics, in situ hybridization and gene array analysis allowed the rapid acquisition of the fundamentals of the biology/genetics of sarcomas (2). However, these techniques are not affordable for all laboratories. The cytogenetic techniques (Fig. 2a) and those associated with polymerase chain reaction (PCR) technology (Fig. 2b and c) have instead allowed us to extend the possibility to identify gene translocations/amplifications specific for these tumors in all diagnostic pathology laboratories, making the costs and methods more affordable for all.

In this review, we summarize not only all known chromosomal aberrations associated with soft tissue tumors, but also the different methods that help identify them and characterize the fusion transcripts produced.

\section{Adipocytic tumors}

Lipogenic tumors represent a heterogeneous group of lesions, mainly represented by liposarcomas. Among the principal histological subtypes of liposarcoma, myxoid liposarcoma (MLS) is the second most common, followed by well-differ- 
entiated liposarcoma (3), that have not been implicated in such chromosomal translocations or fusion genes.

Lipoblastoma. Lipoblastomas are pediatric neoplasms, typically benign lesions, composed of adipose cells in different stages of maturation within a variably myxoid matrix, and they contain clonal rearrangements of chromosome band $8 \mathrm{q} 12$. In lipoblastomas, several chromosomal rearrangements have been described, involving the pleiomorphic adenoma gene 1 (PLAG1) oncogene. In particular, it was shown that the hyaluronic acid synthase 2 (HAS2) or collagen $1 \alpha 2$ (COL1A2) gene promoter regions are fused to the entire PLAG1 coding sequence (4). The PLAG1 status was investigated through in situ hybridization techniques, particularly fluorescence detection [fluorescence in situ hybridization (FISH)] and chromogenic detection [chromogenic in situ hybridization (CISH)] (5).

$M L S$. The non-random reciprocal translocation $\mathrm{t}(12 ; 16)(\mathrm{q} 13 ; \mathrm{p} 11)$ is a characteristic of MLS (6,7). FISH is an alternative to ancestral cytogenetic methods, using painting probes against the centromeres of chromosome 12 metaphases and interphase nuclei (8-10). Early studies using FISH relied on the use of cosmid probes derived from YAC clones, which map at the CHOP locus $(11,12)$. Currently, centralized laboratories specialized in FISH for the diagnosis of sarcomas, use dual-color, break-apart FISH probes spanning the genomic regions of FUS (16p11) (Vysis Inc., Downers Grove, IL, USA) $(13,14)$.

Using Southern blot techniques, in samples with cytogenetic rearrangements in the region $12 \mathrm{q} 13$, it has been shown that CHOP/DDIT3 $\mathrm{t}(12 ; 16)(\mathrm{q} 13 ; \mathrm{p} 11)$ is the gene involved in translocation (15). A chimeric transcript between the CHOP gene, which encodes a transcription factor, and the gene TLS/FUS that localizes in the region $16 \mathrm{p} 11$, is produced $(16,17)$. The protein FUS/TLS interacts with several nuclear receptors and specific transcription factors. Through RT-PCR (18), different variants of the fusion transcript FUS/CHOP can be detected. The most frequent variants are the I and II variants, which are generated by alternative splicing between exon 2 of CHOP and exons 5 and 7 of the FUS gene (19-22). The different expression profile of the transcript FUS/CHOP has also been revealed by nested-PCR $(23,24)$ or nested-PCR and direct sequencing $(25,26)$ in frozen or paraffin-embedded biopsies. Cloning studies have demonstrated that the different variants have similar activities in transforming mesenchymal cells using the same molecular pathways (27).

Real-time PCR is a more specific and sensitive technique for both frozen and formalin-fixed, paraffin-embedded (FFPE) tissues (28). The TLS-CHOP chimeric product is also capable of promoting the development of MLS and tumorigenesis through the repression of the expression of a microRNA, miR-486, as demonstrated in studies on cloned cell lines from NIH3T3 fibroblasts and MLS tissues (29).

MLS can also present the $\mathrm{t}(12 ; 22)(\mathrm{q} 13, \mathrm{q} 12)$ aberration with its chimeric transcript EWS/CHOP fusion between exon 7 of the EWS gene and exon 2 of CHOP. FISH is an excellent method for detecting the presence of gene rearrangements in CHOP, but RT-PCR is the only method able to detect fusion partners, FUS or EWS $(30,31)$. Patients who exhibit these fusion products show a more favorable clinical history compared to other patients positive for transcripts and different variants. Therefore, a correct diagnosis also related to biomolecular data is important, particularly in cases where the myxomatous change is minimal compared to their dominant counterparts which resemble pleomorphic malignant fibrous histiocytoma (32).

\section{Fibroblastic/myofibroblastic tumors}

Fibrosarcoma is a primary malignant tumor composed of immature fibroblasts. Several forms are recognized: infantile fibrosarcoma, which presents at birth or in early childhood, identical to the adult form apart from the clinical course and is much more favorable, as well as dermatofibrosarcoma protuberans (DFSP).

Infantile fibrosarcoma. Infantile fibrosarcoma has the same characteristics of benign lesions of childhood, such as infantile fibromatosis and myofibromatosis (33). The specific translocation $\mathrm{t}(12 ; 15)(\mathrm{p} 13 ; \mathrm{q} 25)(34)$, which makes the differential diagnosis possible, was identified by cytogenetic techniques and cloning of chromosome break sequences. FISH is a specific method, although more costly, and can be used to determine the status of chromosomal rearrangements of the regions 12 p13 and 15q25 (35). Early studies were carried out using FISH probes or chromosome-specific bacterial artificial chromosome (BAC) clone probes (36). These were then replaced by commercial probes for dual-color fusion, the Ets variant 6 (ETV6) gene (Abbott Molecular, Inc., Des Plaines, IL, USA) (37).

The translocation generates a fusion transcript ETV6neurotrophic tyrosine kinase, receptor, type 3 (NTRK3). The ETV6 gene is localized on chromosome arm 12p13, while the NTRK3 gene is in the chromosomal region 15q25 (38). Techniques of cloning and sequencing have shown that the fusion occurs between exon 5 of the ETV6 gene and exon 13 of the NTRK3 gene $(38,39)$. Reverse transcriptase PCR (RT-PCR) is a specific method, fast and economical, for determining the presence of the fusion gene, ETV6-NTRK3, in fresh tissue samples or archived material (40-42).

DFSP. DFSP is a rare variant that is derived from the fibrous component of the dermis and grows slowly, forming ulcers on the skin and subcutaneous tissues. The translocation $t(17 ; 22)$ (q22;q13) is highly specific for DFSP and can generate a chimeric transcript COL1A1/platelet-derived growth factor subunit B (PDGFB) and a supernumerary ring chromosome, $\mathrm{r}(17,22)(43,44)$.

Early studies on the detection of chromosomal translocations by FISH, were based on chromosome painting and $\alpha$-satellite probes. Later studies reported the use of a dual-color dual-fusion BAC probe for COL1A1/PDGFB translocation, obtained by cloning vectors, BACs, covering the PDGFB gene entirely. In this manner, the different variants of the chimeric transcript were identified $(45,46)$. Currently, commercial FISH probes are available, e.g., ZytoLight-SPEC COL1A1PDGFB Dual Color Dual Fusion Probe (ZytoVision GmbH, Bremerhaven, Germany) (47). Different methods, such as Southern blot analysis, RT-PCR and FISH, based on frozen tissue specimens or using archival FFPE tumor samples have 


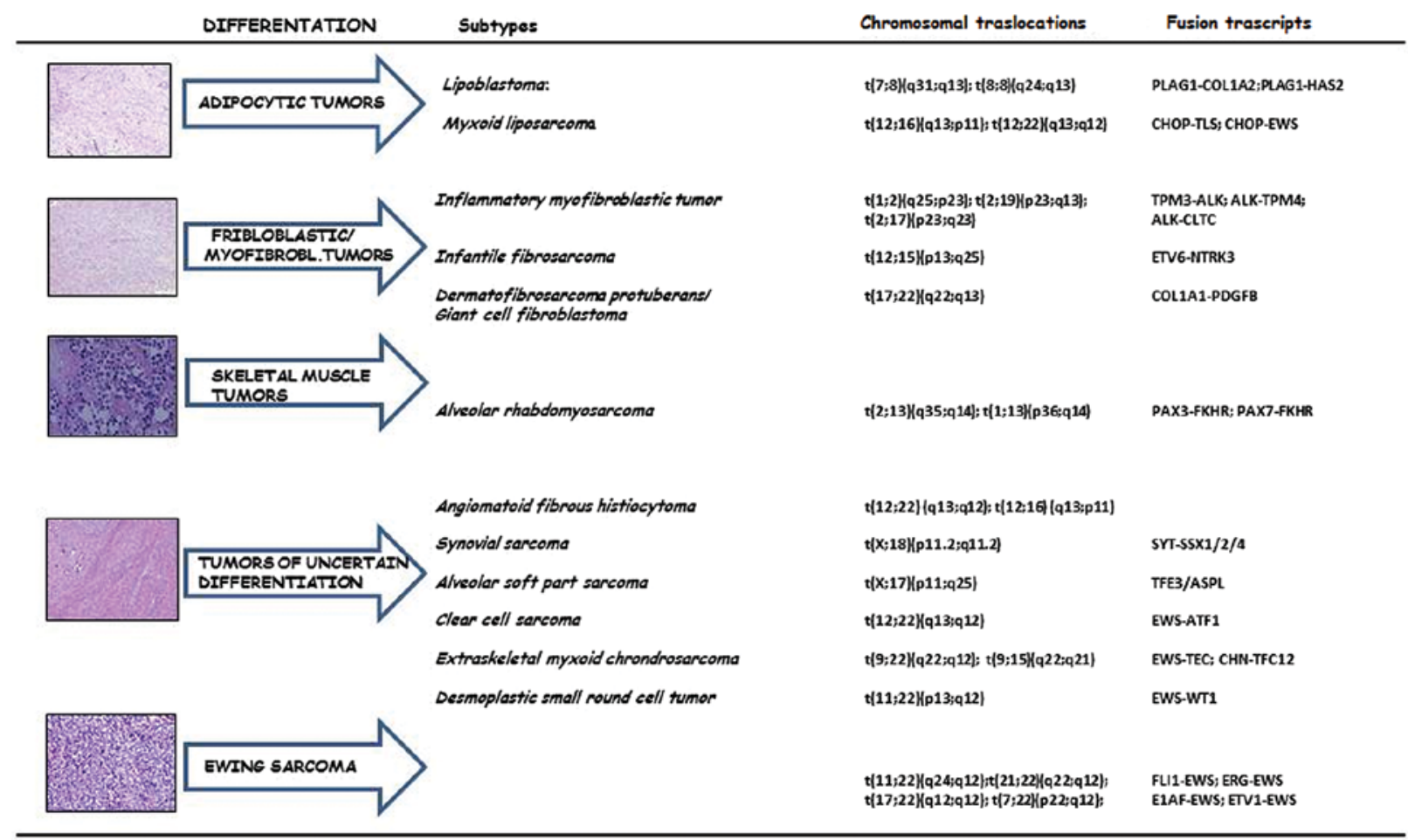

Figure 1. Schematic representation of soft tissue tumors, grouped on the basis of cell line differentiation, with chromosomal translocations and chimeric proteins produced.

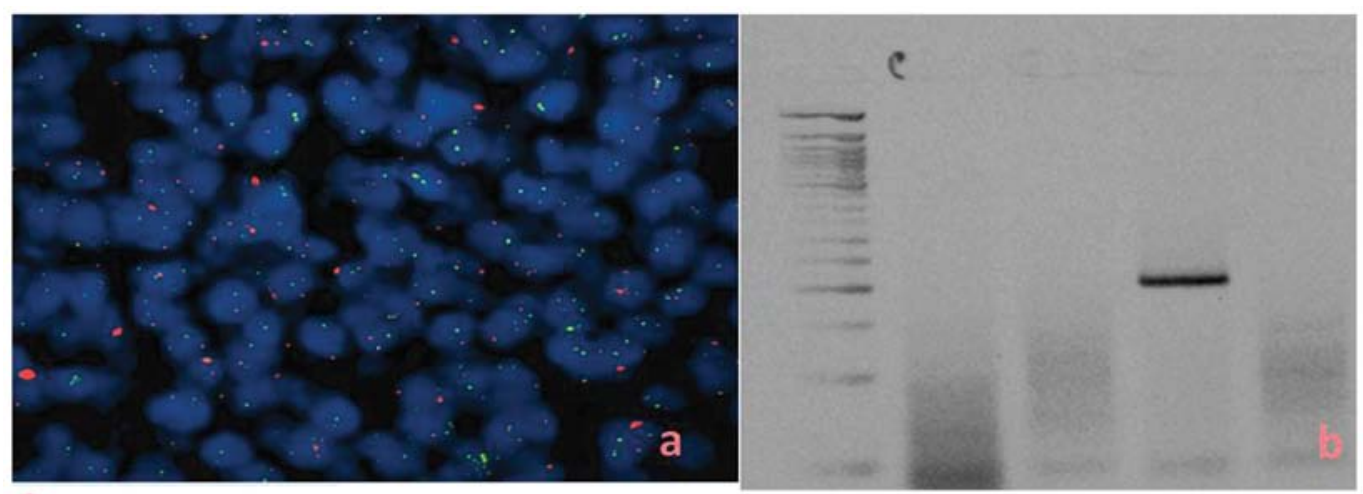

C

Amplification curves

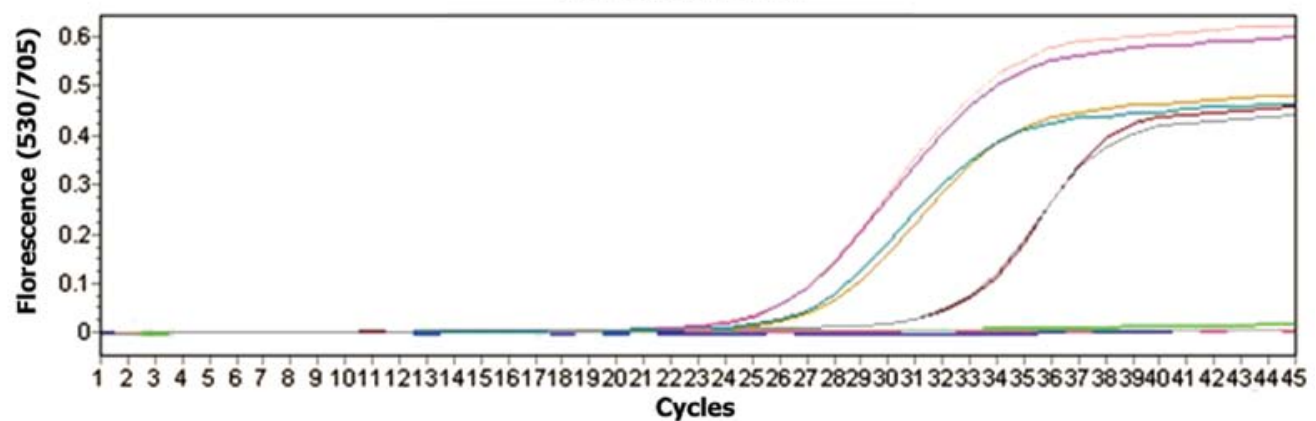

Figure 2. Different methods for gene translocation detection: (a) fluorescence in situ hybridization (FISH) (Vysis LSI CHOP Dual Color Break-apart Rearrangement Probe in a myxoid liposarcoma sample); (b) RT-PCR (fusion transcript of 195 bp in a myxoid liposarcoma sample); (c) real-time PCR (amplification curves associated to fusion transcripts in several myxoid liposarcoma samples).

shown that COL1A1/PDGFB chimeric genes are present in all cases of DFSP $(43,48,49)$.

Finally, to detect the copy number changes on the chromosomal regions, $17 \mathrm{q}$ and $22 \mathrm{q}$, comparative genomic hybridization
(CGH) studies have been performed, and have confirmed the amplification of $17 q$, but not always that of $22 q(50,51) 1$. The breakpoint is at the level of exon 2 of PDGFB in the region 22q, but may involve several exons of the COL1A1 gene 
in the region 17q, such as exons $8,10,22,24,27,32,34,38,40$, 45,46 and 47 , as shown by RT-PCR followed by sequencing analysis $(52,53)$. The same methodology has allowed to identify additional variants of chimeric transcript, such as the one due to fusion at the level of exon 2 of PDGFB with COL1A1 gene but at the level of exon 41 (54). All possible variants of the fusion transcript can be detected using either multiplex RT-PCR (55) or FISH on paraffin-embedded tissues (46).

Real-time PCR provides a more sensitive alternative for analyzing the presence of the fusion transcript or the amplification of the regions affected by the rearrangement in fresh tissue or archived samples (56). Real-time PCR also allows the quantification of mRNA transcripts and the PDGFB chimeric gene, which is overexpressed compared to benign counterparts (normal tissue or dermatofibroma) $(57,58)$.

\section{Skeletal muscle tumors}

Rhabdomyosarcomas originate most often in striated muscles at the level of the arms and legs and are more common in children than in adults. Three main forms are known: polymorphous rhabdomyosarcoma and alveolar rhabdomyosarcoma in adults, and embryonal rhabdomyosarcoma, which is more common in children. The tumor is ubiquitous and the most common sites are the arms, but also the head and neck, the urogenital tract and retroperitoneum. The progression is extremely aggressive, with a great tendency to recurrence and metastasis. The alveolar variant tends to have a worse prognosis than the embryonal variant.

Alveolar rhabdomyosarcoma. Two chromosomal translocations, $\mathrm{t}(2 ; 13)(\mathrm{q} 35 ; \mathrm{q} 14)$ and $\mathrm{t}(1 ; 13)(\mathrm{p} 36 ; \mathrm{q} 14)$, are present in approximately $80 \%$ of all alveolar rhabdomyosarcoma cases (59-61).

The presence of $t(2 ; 13)$ in rhabdomyosarcoma cell lines was demonstrated by ancillary approaches, such as classical cytogenetics and FISH, using painting cosmid probes labeled with digoxigenin and biotin on both metaphases and interphase nuclei (62). $\mathrm{t}(2 ; 13)(\mathrm{q} 35 ; \mathrm{q} 14)$ was firstly detected by FISH on interphase nuclei in minimally invasive biopsies of patients treated with neoadjuvant chemotherapy and then on non-suitable tumor material. In early hybridization studies, two cosmid clones were used in interphase cells with inserts of regions proximal or distal to the $13 \mathrm{q} 14$ breakpoint and a yeast clone with the inserted region distal to the $2 \mathrm{q} 35$ point (63). Present commercial dual-split-signal color FISH probes (Abbott Molecular) are more sensitive and specific to chimeric products, due to the two translocations involving the $13 \mathrm{q} 14$ region $(64,65)$.

Studies on cDNA cloning and sequencing have shown that $\mathrm{t}(2 ; 13)(\mathrm{q} 35 ; \mathrm{q} 14)$ produces a fusion transcript between the paired box 3 (PAX3) gene and FKHR gene, respectively $(66,67)$; the PAX7-FKHR fusion transcript results from the $t(1 ; 13)$ translocation (68).

However, the survival and mortality rate in metastatic patients depend on the rearrangement type: the 4-year survival rate is $75 \%$ for patients with PAX7-FKHR vs. $8 \%$ for those with PAX3-FKHR. If PAX3-FKHR is expressed, there is a significant risk of death $(\mathrm{P}=0.019)$; besides, these patients may present bone marrow involvement (69).
The technical related issues associated with FISH in the diagnosis of alveolar rhabdomyosarcoma in children have been avoided by using RT-PCR, although this method is less sensitive than FISH (70,71); however, the chimeric transcript PAX3/FKHR has been detected in cell lines and in fresh tissue samples and FPPE samples using only very small amounts of tumor tissue $(72,73)$. With multiplex RT-PCR it is also possible to calculate the residual disease (74) and allows the differential diagnosis of alveolar rhabdomyosarcoma and ES (72).

The presence of both translocation $\mathrm{t}(2 ; 13)(\mathrm{q} 35 ; \mathrm{q} 14)$ and $\mathrm{t}(1 ; 13)(\mathrm{p} 36 ; \mathrm{q} 14)$ products is detected with specific primers for the regions flanking the breakpoints in $13 \mathrm{q}$ and $1 \mathrm{p}$, as well as for $2 q$ (75), with RNA extracted from fresh or frozen tissue and formalin-fixed, paraffin-embedded tissue samples (76). The quality of the extracted RNA and the absence of specific primers for unusual variants are the technique limitations, but certainly the problems related to RNA quality will be reduced with fresh or frozen meterial or with the increase in the number of neoplastic cells after laser capture microdissection (77). The specificity of the test is very high (94-100\%), compared to electrophoresis on an agarose gel. Discordant data have been obtained by analyzing the same samples by Southern blot analysis (78). A correct diagnosis also requires ancillary data, such as clinical history, immunohistochemistry and histology, while the uncertain cases may require further FISH investigation.

Multiplex fluorescent analysis of chromosomal translocations (MFACT) is another alternative method which can be used in place of conventional RT-PCR. This method has the advantage of completely eliminating the manipulation of the PCR products and thus it greatly reduces the risk of crosscontamination (79).

Real-time PCR using a hydrolysis probe, is a highly sensitive and specific method that reveals and further quantifies the chimeric transcripts PAX3-FKHR and PAX7-FKHR in the peripheral blood of patients, yielding similar results to nested-PCR. Patients positive for the fusion transcripts are at high risk of tumor progression (80). An initial screening for immunohistochemistry helps to select patients for molecular investigations, since it has been shown that only patients with alveolar rhabdomyosarcoma and not those with the embryonic phenotype that present with $>50 \%$ of cells immunoreactive for myogenin, show the rearrangement of PAX (81).

\section{Tumors of uncertain differentiation}

Tumors that escape histological classification, as they lack a definite differentiation from a certain type of mesenchymal tissue, are encompassed in this category. They mostly occur between the ages of 15 and 40 years and are more common in males.

Synovial sarcoma. Synovial sarcoma is the most common lesion in this group. The peak of incidence is the third decade of life, and the male/female incidence ratio is approximately 1.2:1. Synovial sarcoma can be mono- or biphasic and the difference is at the histopathological level: biphasic synovial sarcoma presents with epithelial and spindle cells, while monophasic synovial sarcoma almost always presents with spindle cells. 
The $\mathrm{t}(\mathrm{x} ; 18)(\mathrm{p} 11.2 ; \mathrm{q} 11.2)$ translocation has been observed in patients with this neoplasm, often as a unique cytogenetic abnormality (82), for which the SYT gene on chromosome 18 is juxtaposed to one of the two genes related, SSX1 or SSX2, but distinct on chromosome X $(83,84)$.

The first cytogenetics and FISH studies on paraffin-embedded samples were performed using centromeric probes together with whole chromosome painting probes for chromosomes $\mathrm{X}$ and $18(85)$. The translocation $(\mathrm{X} ; 18)(\mathrm{p} 11 ; \mathrm{q} 11)$ breakpoint has been demonstrated by both Southern blot analysis and FISH analysis using specific yeast artificial chromosome (YAC) probes $(86,87)$. Dual-color break-apart probes, synthesized by cloning the breakpoint regions of interest in BAC clones and labeled with fluorescein-12-dUTP and TexRed-5-dUTP, were very useful in CISH and FISH (88). Currently, interphase FISH is performed on fixed, paraffin-embedded tissues using a commercially available LSI SS18 dual-color break-apart probe (Abbott Molecular/Vysis Inc.), a more specific and sensitive probe than non-commercial CISH probes $(89,90)$.

The SS18-SSX chimeric product was detected even in FFPE samples by ISH using biotinylated tyramide and probes labeled with digoxigenin specific for the cDNA. The method produces signals in epithelial cells of biphasic sarcomas, with mild or focal positivity in monophasic tumors (91).

RT-PCR has a specificity of $100 \%$ with a sensitivity of $96 \%$ for the detection of the fusion transcript in paraffin-embedded lesions with the $\mathrm{t}(\mathrm{X} ; 18)$ (SYT-SSX) translocation, limited only by the use of particular fixatives that produce a poor quality of extracted RNA $(92,93)$. The molecular analysis evaluates the incidence of molecular variants, using sets of specific primers for SS18-SSX1 and SS18-SSX2; however, a statistically significant association between histological subtype (monophasic vs. biphasic) and SSX1 or SSX2 (94) has not been found. New variants for both SS18-SSX1 and SS18-SSX2 have been shown by sequencing the products of RT-PCR (95-97).

FISH and RT-PCR investigations are useful and necessary in those cases where the differential diagnosis between synovial and other spindle cell sarcomas (98) is difficult.

The fusion transcripts are detected and quantified by real-time RT-PCR, more sensitive and rapid than RT-PCR, using specific primers and TaqMan fluorescent probes complementary to the breakpoints in the genes involved in the translocation (99-101). Multiplex real-time PCR analyzes all variants of chimeric transcripts together, using appropriate sets of primers and probes: SS18-SSX1 has been shown to be present in both monophasic and biphasic synovial sarcomas more frequently than the SS18-SSX2 variant. They are mutually exclusive (102).

Clear cell sarcoma (CCS). CCS is a malignancy that can be morphologically confused with non-cutaneous melanoma as it presents the same immunophenotype. The differential diagnosis is possible thanks to the translocation $\mathrm{t}(12 ; 22)(\mathrm{q} 13 ; \mathrm{q} 12)$, for which the chimeric gene EWSR1/ATF1 is formed in melanocytic tumors of soft tissues. Less commonly, CCS can be marked by $\mathrm{t}(2 ; 22)(\mathrm{q} 34 ; \mathrm{q} 12)$, which produces the fusion transcript, EWSR1/CREB1, typical of gastrointestinal CCS, but that can also characterize CCS of soft tissue (103).

In order to characterize the translocation and its chimeric product, the first studies were conducted on cell lines, such as
$\mathrm{KAO}$, obtained from a girl of 9 years, or the HS-MM. melanoma cells, which were used as negative controls for $\mathrm{t}(12 ; 22)$; CCS cells alone have been shown to be positive for the translocation and the EWS/ATF1 fusion gene, analyzed by FISH and RT-PCR, respectively (104).

Nowdays, slides of FPPE samples and tumor microarray (TMA) are routinely analyzed by interphase FISH with commercial probes LSY EWS dual-color break-apart (Vysis Inc.) and the positive cases can be analyzed by RT-PCR to determine the type of chimeric transcript EWS ATF1 (105,106). All cases of melanoma are negative to FISH for the same region, the 22q12 (107).

Four variants of the fusion transcript are detected by RT-PCR and sequencing, due to different breakpoints in the relevant gene regions: three subtypes are due to in-frame fusion and are type 1,2 and 3, due to the fusion-EWS exon 8 and ATF1exon 4, EWS-ATF1-exon 7 and 5, and EWS-ATF1-exon 10 and 5, respectively; the subtype 4 is due to the out-of-frame fusion of the region with exon 7 of EWS and exon 7 of ATF1. In addition to these four main transcripts, which may also occur together, there can be out-of-frame fusion between exon 10 of EWS and 3 of ATF1, or between exon 8 of EWS and 4 of ATF1, with insertion of nucleotides at the junction point $(108,109)$. RT-PCR is performed using extracted RNA from either frozen or FFPE tissue (110).

Real-time PCR is much more sensitive than classical RT-PCR, and is highly specific and very helpful in the differential diagnosis of melanoma, on fresh or frozen or FPPE samples (111).

Desmoplastic small round-cell tumor (DSRCT). DSRCT is a rare and aggressive malignancy, with typical localization to serosa of the abdominal-pelvic peritoneum, with a male/female incidence ratio of 4:1 and occurs during adolescence or early adulthood. In $40 \%$ of patients, it metastasizes to the liver, lungs and lymph nodes.

The tumor shows epithelial and mesenchymal properties and neural differentiation, and the cells present the translocation $\mathrm{t}(11 ; 22)(\mathrm{p} 13 ; \mathrm{q} 12)$, which juxtaposes the gene, EWSR1, to the tumor suppressor gene, WT1 $(112,113)$, whose identification in specialist laboratories is very helpful for a correct differential diagnosis, complicated by similarities with other small round cell tumors. The fusion protein EWSR1/WT1 acts as a potent transcriptional activator (114).

In clinical diagnostics of FFPE tissue sections, interphase FISH is routinely performed with a commercially available EWSR1 (22q12) dual color, break-apart rearrangement probe, but the $\mathrm{t}(11 ; 22)$ is also found in $90 \%$ of EWS/primitive neuroectodermal tumor (PNET) and CCS cases (105).

The biological differences between DSRCT, ES and CCS can be explained by the presence of the different partners in the EWS gene translocation. Studies using Southern blot analysis, multi-enzymatic digestion and northern blot analysis have demonstrated that gene rearrangement in the region $22 \mathrm{q} 12$ produces the fusion of the EWS gene on 11p13 with WT1, the gene involved in Wilms tumor. RT-PCR, with the use of a primer for exon 7 of EWS and primers for exons 8 or 9 of WT1, confirmed the data (115). The chimeric mRNA is due to an in-frame fusion of the amino-terminal domain of EWS with the zinc-finger DNA-binding domain of WT1, which can 
undergo alternative splicing (116). Chromosomal translocation and fusion with EWS affect two independent biochemical functions of WT1, binding activity to DNA and transcriptional regulation, a deregulation that influences tumorigenesis in intra-abdominal DSRCT $(114,117)$.

The variability in the breakpoint EWS produces molecular variants of the fusion gene EWS-WT1, as happens for the chimeric gene EWS-FLI1 in ES, such as an in-frame splicing of exon 9 of EWS to exon 8 of WT1, a variant found in a DSRCT unusually arising on hand, or an in-frame junction of EWS to exons 8-10 of WT1 (118).

To differentiate DSRCT from EWS/PNET, when the genetic information is not available, immunohistochemistry is recommended with an anti-WT1 antibody, highly specific and sensitive, that is a reliable index for the presence of the EWS-WT1 chimeric product (119).

RT-PCR can detect all chimeric messages that are formed by fusion between exons 1-7 of EWS and exons 8-10 of WT1 (120). Multiple in-frame cDNA can be also detected. It is produced by large internal deletions, insertions of small parts of heterologous DNA at the site of the junction between the two exons EWS and WT1, or the loss of exon 6 of EWS or exon 9 of WT1. The molecular diversity and functionality of these fusion transcripts may have significant biological implications for their tumorigenic potential (121).

Inflammatory myofibroblastic tumor (IMT). IMT is a mesenchymal tumor that presents with fibroblastic and myofibroblastic spindle cell proliferation mixed with lymphocytes, plasma cells and histiocytes (122). It can commonly occur in children, teenagers and adults under the age of 40 . It was described for the first time in lungs and remains the most frequent mesenchymal endobronchial tumor in childhood (123). IMT can localize in any anatomical site, but it rarerly occurs in the liver. The lesion often presents with ambiguous morphological, structural and vascular properties, since it has both an inflammatory and neoplastic nature and therefore, diagnosis can be difficult.

Cytogenetic analysis has revealed clonal chromosomal abnormalities exhibiting the neoplastic nature of the disease. Approximately half of inflammatory myofibroblastic tumors present rearrangements of the locus of the anaplastic lymphoma kinase (ALK) gene on chromosome 2p23, resulting in the aberrant expression of ALK. FISH of interphase nuclei of FPPE samples were carried out using a commercial dualcolor (red and green) ALK probe (Vysis Inc.), that labeled at telomeric region in SpectrumOrange and at centromeric region in SpectrumGreen of chromosome 2 (124,125). FISH leads to a correct diagnosis of IMT, even in cases in which the inflammatory component is minimal and during prenatal life as well (126). It is also possible to perform FISH on samples of fine needle aspiration (FNA) or endoscopic ultrasound-guided FNA (EUS-FNA) $(127,128)$.

The disease can also present morphological characteristics of other similar lesions, such as child congenital fibrosarcoma (CIFS) and hemangiopericytoma, but the identification of the present transcript fusion by RT-PCR facilitates the correct diagnosis $(129,130)$.

ALK, which is normally downregulated in neural tissues, is overexpressed in IMT cells with the 2p23 rearrangement, in which the N-terminal domain of tropomyosin (TPM) is fused to the C-terminus of ALK. Cloning studies have shown two fusion products, TPM4-ALK and TPM3-ALK, which encode for oncoproteins with constitutive kinase activity $(131,132)$. RT-PCR seems the best method to identify the ALK fusion transcripts $(133,134)$.

ALK can be also fused with clathrin heavy chain (CTLC), a gene localized to $17 \mathrm{q} 23$; however, patients that are $\mathrm{t}(2 ; 17)$ positive show other abnormal karyotypes as well (135).

RT-PCR with specific pairs of primers and direct sequencing of the amplification products have also enabled the identification of new partners of ALK, such as dynactin-1, when the alteration $\operatorname{der}(2) \mathrm{t}(2 ; 12)(\mathrm{p} 23 ; \mathrm{q} 11)$ is present $(136)$, or when the SEC31L1/ALK fusion gene, due to translocation $\mathrm{t}(2 ; 4)(\mathrm{p} 23 ; \mathrm{q} 21)$, is present in two variants of different lengths (137).

A partial response by the inhibitor of ALK, crizotinib, has been reported in a patient with inflammatory myofibroblastic tumor with ALK translocation $(138,139)$.

Alveolar soft-part sarcoma (ASPS). ASPS represents approximately $0.5-1 \%$ of soft tissue sarcomas and typically develops in adolescents and young adults; in children the localization is typical on the head and neck $(140,141)$. Although growth is indolent, up to $79 \%$ of patients develop metastatic disease, since a significant percentage of them is resistant to conventional chemotherapeutic drugs. The development of chemoresistant metastases contributes to the increase in the mortality rate.

The translocation $\operatorname{der}(17) \mathrm{t}(\mathrm{X} ; 17)(\mathrm{p} 11 ; 25)$ is the ASPS biomolecular marker (142) that causes the fusion of the transcription factor, TFE3, on Xp11.22, with a novel gene on 17q25, termed ASPL (ASPSCR1). The chimeric product, ASPL-TFE3, acts as a transcription factor and induces an aberrant transcription of genes regulated by TFE3 $(143,144)$.

The translocation is confirmed by dual-and triple-color FISH on metaphases and interphase nuclei (145). Early studies of fluorescence in situ were performed using YAC and cosmid probes from the genomic regions of interest (146).

RT-PCR can be performed on frozen and FPPE tumor tissue to detect the presence of the resulting ASPSCR1-TFE3 fusion transcripts and its variants. The location of the fusion transcript, if present, leads to the proper diagnosis of ASPS, previously considered as a subgroup of RCC in children $(147,148)$. The chimeric products of $t(X ; 17)(p 11 ; 25)$ are detected by nested RT-PCR, which is more sensitive, also in circulating tumor cells in peripheral blood of ASPS patients with distant metastases (149).

Preliminary clinical studies have shown that patients with ASPS positive for $\operatorname{der}(17) \mathrm{t}(\mathrm{X} ; 17)(\mathrm{p} 11 ; 25)$ respond to treatment with trabectedin, the only currently available clinical drug which has shown to be effective in the treatment of this disease (150).

Extraosseous myxoid chondrosarcoma (EMC). EMC presents strings of small acidophilic cells similar to chondroblasts in a myxoid stroma, and occurs particularly in the lower extremities, particularly in the fifth decade of life with a male/female incidence ratio of 2:1 (151). Patients may have long-term survival; however, local recurrences and metastases occur in approximately half of the cases, commonly in the lungs (152-154). Unlike bone chondrosarcoma, EMC behaves in a less aggres- 
sive manner. Therefore, it is deemed as two prognostically distinct entities (152).

Previous cytogenetic data have included a translocation $\mathrm{t}(9 ; 22)(\mathrm{q} 22-31 ; \mathrm{q} 12)$, that produced the EWS/CHN chimeric gene and showed complex karyotypes $(155,156)$. The translocation $\mathrm{t}(9 ; 17)(\mathrm{q} 22 ; \mathrm{q} 11.2)$ is less frequent and combines with the $\mathrm{CHN}$ RBP56 gene, also known as TAF15, TAF2N or TAFII68 (157). A third translocation was also identified, typical of EMC, but less common, affecting chromosomes 9 and 15 and forming the chimeric gene, $\mathrm{CHN} / \mathrm{TCF} 12$. Gene TCF12, also known as HTF4, presents different isoforms by alternative splicing and the breakpoint affects the region of intron $5(158,159)$. Further molecular analyses have revealed additional chromosomal aberrations that can aid in the diagnosis of EMC, identifying other chimeric variants, such as the fused trascript $T F G$ (TRK-fused gene)/CHN associated with t(3;9)(q11-q12;q22) $(156,160,161)$.

The translocation occurs due to different breakpoints in various introns of the gene, EWS and CHN (termed NR4A3, NOR1 or TEC) (162), resulting in different variants of the chimeric products, EWS/CHN. The most frequent are: type 1, for the fusion between exons 12 of EWS and 3 of $\mathrm{CHN}$, and type 5, between exons 13 of EWS and 3 of CHN. The chimeric gene RBP56/CHN is always formed by fusion between exons 6 of RBP56 and 3 of CHN. The mapping of the different regions of breakpoints in the EWS and $\mathrm{CHN}$ genes has shown that there are no sequence-specific recombinases or homology to explain the various breakpoints, due to other associated events such as deletions, duplications and inversions (163).

In FISH on formalin-fixed, FNA biopsy and paraffinembedded tissues, using commercial LSY EWSR1 (22q12) dual-color, break-apart probe (Vysis Inc.), it is possible to demonstrate the presence of the EWSR1 gene rearrangement $(13,164,165)$. The translocation at gene NR4A3 has been shown by dual-color FISH using a custom probe, synthesized by means of BAC and telomeric chromosome clones, labeled with SpectrumGreen and SpectrumOrange (166). Variant translocations were also detected by interphase FISH, such as $\mathrm{t}(9 ; 15)(\mathrm{q} 22 ; \mathrm{q} 21)$ and $\mathrm{t}(7 ; 9 ; 17)(\mathrm{q} 32 ; \mathrm{q} 22 ; \mathrm{q} 11)$, with satellite probes for chromosomes 7,8 and 12, and telomeric probes for 1q and 19q (Vysis Inc.) (167).

RT-PCR on archival FPPE samples, using specific pairs of primers, is a useful technique for detecting both the chimeric products due to the main translocations, such as EWS-CHN or RBP56-CHN (168), and different transcripts from EWSR1/TAF15/TFG-NR4A3 fusion, such as EWSR1-CREB1 fusion transcript which is present in cases of primary pulmonary myxoid sarcoma (169).

\section{Ewing's sarcoma}

ES is a bone cancer, the most frequent after osteosarcoma, histologically characterized by sheets of small round cells, blue staining with $\mathrm{H} \& \mathrm{E}$, which can be confused with lymphoma or embryonic rhabdomyosarcoma. It is rare in newborns and after the age of 30, with a higher incidence at the age of 16. ES and PNET not only have similar microscopic characteristics, but also show the same genetic alteration, a translocation (170-172); thus, they are subsequently grouped in a class of tumors defined as 'Ewing's sarcoma family tumors' (ESFT). The typical translocation affects the region of chromosome 22 in which the family of ETS transcription factors are mapped. In $90 \%$ of cases the chimeric gene has the region of chromosome 11 as a partner of the gene EWS, producing the fusion transcript, EWSR1-FLI1; chromosome 21 is the less frequent partner and in particular the translocation forms the product gene, EWSR1-ERG (173). The region of chromosome 22 with EWSR1 can translocate into other chromosomal regions, $\mathrm{t}(21 ; 22), \mathrm{t}(7 ; 22), \mathrm{t}(17 ; 22)$ and $\mathrm{t}(2 ; 22)$, producing different chimeric transcripts according to the fusion partner (ERG, ETV1, E1AF and FEV) (173-175).

Colorimetric or fluorescence studies have used YAC probes, tested on paraffin-embedded tissue sections (176), while others have used and validated constructed probes on cell lines (177). Using a triple-target FISH on interphase nuclei, metaphase chromosomes and DNA fibers, it has been proven how the transcript EWS/ERG, in particular, may occur. The technique has been performed with co-hybridization of probes cloned in cosmids, complementary to the telomeric and centromeric regions of the region with the EWS breakpoint. FISH, in particular, has shown that an inversion of the ERG gene or part of it may be followed by an insertion in the EWS gene on der(22) (178). It is now of routine use to investigate translocations involving the EWSR1 gene using a dual interphase LSY color break-apart EWS-FISH (179), while the different variations of the formed fusion transcripts have been investigated by RT-PCR with specific pairs of primers (180).

RT-PCR amplifies RNAs extracted from fresh or cryopreserved tissue samples; however, the results are specific and confirmed on archivial FPPE material (181). The method is also sensitive to detect minimal residual disease (182) and a simultaneous detection of all chimeric products can be done using a mixture of primers. This method can be very useful in clinical practice, to guarantee diagnosis, to perform investigations of minimal metastatic and residual disease and to evaluate the prognostic significance of the subtypes of chimeric transcripts even when fresh tumor tissue is not available (182).

The specificity of EWS transcripts with their respective partners for ES was tested using nested RT-PCR on different samples of FPPE tissue $(183,184)$.

Combining the biomolecular investigations by nested RT-PCR, more sensitive than conventional RT-PCR, with cytogenetic analysis by FISH in FPPE samples, a clear diagnosis of ES/PNET is possible. In particular, in situ hybridization of nuclear extraction (NE-FISH) is more reliable than that of thin-section (TS-FISH) in detecting the translocation of EWSR1 (185). The specificity of the amplification product for nested RT-PCR is confirmed by the subsequent digestion of the PCR fragments with different restriction endonucleases, a rapid method to determine the combination of exons present in a chimeric mRNA (186).

The use of western blotting to detect the fusion protein of 68-kDa EWS/FLI1 in samples of surgical biopsies and in fine needle aspirates of ES, also detected in cell lines of ES, bypasses the problems related to the quality of mRNA extracted from paraffin-embedded samples or the risk of contamination in amplification techniques, such as RT-PCR (187).

It is possible to genotype the allelic discrimination for single nucleotide polymorphisms (SNPs) in the EWS gene using a TaqMan assay real-time-PCR. The analysis revealed a higher incidence of the presence of homozygous TT in patients with ES. The analysis also allowed the detection and identified 
the region around the SNP, formed by a hexamer palindrome (5'-GCTAGC-3') and three nucleotides (GTC), very close to the breakpoints in both the EWS and FLI1 genes. In patients homozygous for this set of alleles, there a tendency to fracture doubles, increasing the possibility of a translocation. SNP can be then a candidate marker for susceptibility to ES (188). Moreover, investigations by TaqMan real-time-PCR with a set of pairs of specific primers and probes can quantify the different chimeric transcripts in ES (EWS-FLI1, EWS-ERG, EWS-TV1, EWS-ETV4 and EWS-FEV) (189).

\section{Conclusion}

A number of studies have been undertaken to increase knowledge on chromosomal aberrations and facilitate the diagnosis of subsequent lesions, detecting specific translocations and chimeric products (190-192). The described chromosomal rearrangements not only aid in the diagnosis and classification of soft tissue tumors, but are particularly useful in the differential diagnosis of patients with an uncertain or dubious morphology (193). Routine techniques, such as FISH and RT-PCR, can be within the reach of pathology laboratories, helping the pathologist in the diagnosis of such neoplasms (194). Obviously, as for all biomolecular methods, an essential condition is mandatory for the correct development of these methods and to ensure useful results for diagnosis; this includes all pre-analytical stages of preparation of the biological sample. Appropriate sampling and all stages, ranging from fixation/ inclusion to the cutting of sections destined for FISH and purification of nucleic acids, must be conducted in the correct manner and by established standardized procedures.

\section{References}

1. Dei Tos AP and Dal Cin P: The role of cytogenetics in the classification of soft tissue tumours. Virchows Arch 431: 83-94, 1997.

2. Bennicelli JL and Barr FG: Genetics and the biologic basis of sarcomas. Curr Opin Oncol 11: 267-274, 1999.

3. Christopher DM Fletcher, K Krishnan Unni and Fredrik Mertens (eds): WHO: Pathology and Genetics of Tumours of Soft Tissue and Bone. IARC Press, Lyon, 2002.

4. Gisselsson D, Hibbard MK, Dal Cin P, Sciot R, Hsi BL, Kozakewich HP and Fletcher JA: PLAG1 alterations in lipoblastoma: involvement in varied mesenchymal cell types and evidence for alternative oncogenic mechanisms. Am J Pathol 159: 955-962, 2001.

5. Martins C, Fonseca I, Roque L, Pereira T, Ribeiro C, Bullerdiek J and Soares J: PLAG1 gene alterations in salivary gland pleomorphic adenoma and carcinoma ex-pleomorphic adenoma: a combined study using chromosome banding, in situ hybridization and immunocytochemistry. Mod Pathol 18: 1048-1055, 2005.

6. Turc-Carel C, Limon J, Dal Cin P, Rao U, Karakousis C and Sandberg AA: Cytogenetic studies of adipose tissue tumors. II. Recurrent reciprocal translocation $\mathrm{t}(12 ; 16)(\mathrm{q} 13 ; \mathrm{p} 11)$ in myxoid liposarcomas. Cancer Genet Cytogenet 23: 291-309, 1986.

7. Paulien S, Turc-Carel C, Dal Cin P, Jani-Sait S, Sreekantaiah C, Leong SP, Vogelstein B, Kinzler KW, Sandberg AA and Gemmill RM: Myxoid liposarcoma with $t(12 ; 16)$ (q13;p11) contains site-specific differences in methylation patterns surrounding a zinc-finger gene mapped to the breakpoint region on chromosome 12. Cancer Res 50: 7902-7907, 1990.

8. Mezzelani A, Sozzi G, Pierotti MA and Pilotti S: Rapid differential diagnosis of myxoid liposarcoma by fluorescence in situ hybridisation on cytological preparations. Clin Mol Pathol 49: 308-309, 1996

9. Aoki T, Hisaoka M, Kouho H, Hashimoto $\mathrm{H}$ and Nakata $\mathrm{H}$ : Interphase cytogenetic analysis of myxoid soft tissue tumors by fluorescence in situ hybridization and DNA flow cytometry using paraffin-embedded tissue. Cancer 79: 284-293, 1997.
10. Sozzi G, Minoletti F, Miozzo M, Sard L, Musso K, Azzarelli A, Pierotti MA and Pilotti S: Relevance of cytogenetic and fluorescent in situ hybridization analyses in the clinical assessment of soft tissue sarcoma. Hum Pathol 28: 134-142, 1997.

11. Schoenmakers EF, Kools PF, Mols R, Kazmierczak B, Bartnitzke S, Bullerdiek J, Dal Cin P, De Jong PJ, Van den Berghe $\mathrm{H}$ and Van de Ven WJ: Physical mapping of chromosome $12 \mathrm{q}$ breakpoints in lipoma, pleomorphic salivary gland adenoma, uterine leiomyoma, and myxoid liposarcoma. Genomics 20: 210-222, 1994.

12. Gisselsson D, Mandahl N, Pålsson E, Gorunova L and Höglund M: Locus-specific multifluor FISH analysis allows physical characterization of complex chromosome abnormalities in neoplasia. Genes Chromosomes Cancer 28: 347-352, 2000.

13. Downs-Kelly E, Goldblum JR, Patel RM, Weiss SW, Folpe AL, Mertens F, Hartke M, Tubbs RR and Skacel M: The utility of fluorescence in situ hybridization (FISH) in the diagnosis of myxoid soft tissue neoplasms. Am J Surg Pathol 32: 8-13, 2008.

14. Narendra S, Valente A, Tull J and Zhang S: DDIT3 gene break-apart as a molecular marker for diagnosis of myxoid liposarcoma - assay validation and clinical experience. Diagn Mol Pathol 20: 218-224, 2011.

15. Aman P, Ron D, Mandahl N, Fioretos T, Heim S, Arheden K, Willén H, Rydholm A and Mitelman F: Rearrangement of the transcription factor gene CHOP in myxoid liposarcomas with t(12;16)(q13;p11). Genes Chromosomes Cancer 5: 278-285, 1992.

16. Crozat A, Aman P, Mandahl N and Ron D: Fusion of CHOP to a novel RNA-binding protein in human myxoid liposarcoma. Nature 363: 640-644, 1993.

17. Knight JC, Renwick PJ, Dal Cin P, Van den Berghe H and Fletcher CD: Translocation $\mathrm{t}(12 ; 16)(\mathrm{q} 13 ; \mathrm{p} 11)$ in myxoid liposarcoma and round cell liposarcoma: molecular and cytogenetic analysis. Cancer Res 55: 24-27, 1995.

18. Yang X, Nagasaki K, Egawa S, Maruyama K, Futami H, Tsukada T, Yokoyama R, Beppu Y, Fukuma H, Shimoda T, Mukai K, Yabe H, Hanaoka I, Yabe Y and Yamaguchi K: FUS/TLS-CHOP chimeric transcripts in liposarcoma tissues. Jpn J Clin Oncol 25: 234-239, 1995.

19. Panagopoulos I, Mandahl N, Mitelman F and Aman P: Two distinct FUS breakpoint clusters in myxoid liposarcoma and acute myeloid leukemia with the translocations $t(12 ; 16)$ and $\mathrm{t}(16 ; 21)$. Oncogene 11: 1133-1137, 1995.

20. Willeke F, Ridder R, Mechtersheimer G, Schwarzbach M, Duwe A, Weitz J, Lehnert T, Herfarth C and von Knebel Doeberitz M: Analysis of FUS-CHOP fusion transcripts in different types of soft tissue liposarcoma and their diagnostic implications. Clin Cancer Res 4: 1779-1784, 1998.

21. Kanoe H, Nakayama T, Hosaka T, Murakami H, Yamamoto H, Nakashima Y, Tsuboyama T, Nakamura T, Ron D, Sasaki MS and Toguchida J: Characteristics of genomic breakpoints in TLS-CHOP translocations in liposarcomas suggest the involvement of Translin and topoisomerase II in the process of translocation. Oncogene 18: 721-729, 1999.

22. Huang HY and Antonescu CR: Molecular variability of TLS-CHOP structure shows no significant impact on the level of adipogenesis: a comparative ultrastructural and RT-PCR analysis of 14 cases of myxoid/round cell liposarcomas. Ultrastruct Pathol 27: 217-226, 2003.

23. Panagopoulos I, Aman P, Mertens F, Mandahl N, Rydholm A, Bauer HF and Mitelman F: Genomic PCR detects tumor cells in peripheral blood from patients with myxoid liposarcoma. Genes Chromosomes Cancer 17: 102-107, 1996.

24. Rivero ER, Mesquita RA, de Sousa SC and Nunes FD: Detection of TLS/FUS-CHOP fusion transcripts in a case of oral liposarcoma. Ann Diagn Pathol 10: 36-38, 2006.

25. Panagopoulos I, Lassen C, Isaksson M, Mitelman F, Mandahl N and Aman P: Characteristic sequence motifs at the breakpoints of the hybrid genes FUS/CHOP, EWS/CHOP and FUS/ERG in myxoid liposarcoma and acute myeloid leukemia. Oncogene 15: $1357-1362,1997$.

26. Hisaoka M, Tsuji S, Morimitsu Y, Hashimoto H, Shimajiri S, Komiya S and Ushijima M: Detection of TLS/FUS-CHOP fusion transcripts in myxoid and round cell liposarcomas by nested reverse transcription-polymerase chain reaction using archival paraffin-embedded tissues. Diagn Mol Pathol 7: 96-101, 1998. 
27. Schwarzbach MH, Koesters R, Germann A, Mechtersheimer G, Geisbill J and Winkler S: Comparable transforming capacities and differential gene expression patterns of variant FUS/CHOP fusion transcripts derived from soft tissue liposarcomas. Oncogene 23: 6798-6805, 2004.

28. Patil N, Abba M, Hödl P, Schwarzbach M and Allgayer H: A real time PCR based approach for the quantitative detection of FUS-CHOP fusion transcripts in human liposarcoma. Adv Med Sci 57: 37-45, 2012

29. Borjigin N, Ohno S, Wu W, Tanaka M, Suzuki R, Fujita K, Takanashi M, Oikawa K, Goto T, Motoi T, Kosaka T, Yamamoto K and Kuroda M: TLS-CHOP represses miR-486 expression, inducing upregulation of a metastasis regulator PAI-1 in human myxoid liposarcoma. Biochem Biophys Res Commun 427: 355-360, 2012

30. Suzuki K, Matsui Y, Endo K, Kubo T, Hasegawa T, Kimura T, Ohtani $\mathrm{O}$ and Yasui N: Myxoid liposarcoma with EWS-CHOP type 1 fusion gene. Anticancer Res 30: 4679-4683, 2010.

31. Powers MP, Wang WL, Hernandez VS, Patel KS, Lev DC, Lazar AJ and López-Terrada DH: Detection of myxoid liposarcoma-associated FUS-DDIT3 rearrangement variants including a newly identified breakpoint using an optimized RT-PCR assay. Mod Pathol 23: 1307-1315, 2010.

32. Suzuki K, Matsui Y, Hashimoto N, et al: Variation in myxoid liposarcoma: Clinicopathological examination of four cases with detectable TLS-CHOP or EWS-CHOP fusion transcripts whose histopathological diagnosis was other than myxoid liposarcoma. Oncol Lett 3: 293-296, 2012.

33. Bourgeois JM, Knezevich SR, Mathers JA and Sorensen PH: Molecular detection of the ETV6-NTRK3 gene fusion differentiates congenital fibrosarcoma from other childhood spindle cell tumors. Am J Surg Pathol 24: 937-246, 2000.

34. Knezevich SR, McFadden DE, Tao W, Lim JF and Sorensen PH: A novel ETV6-NTRK3 gene fusion in congenital fibrosarcoma. Nat Genet 18: 184-187, 1998

35. Adem C, Gisselsson D, Dal Cin P and Nascimento AG: ETV6 rearrangements in patients with infantile fibrosarcomas and congenital mesoblastic nephromas by fluorescence in situ hybridization. Mod Pathol 14: 1246-1251, 2001

36. Morerio C, Rapella A, Rosanda C, Tassano E, Conte M Gambini C and Panarello C: Differential diagnosis of congenital fibrosarcoma. Cancer Genet Cytogenet 152: 167-168, 2004.

37. Mariño-Enríquez A, Li P, Samuelson J, Rossi MR and ReyesMúgica M: Congenital fibrosarcoma with a novel complex 3-way translocation $\mathrm{t}(12 ; 15 ; 19)$ and unusual histologic features. Hum Pathol 39: 1844-1848, 2008.

38. Knezevich SR, Garnett MJ, Pysher TJ, Beckwith JB, Grundy PE and Sorensen PH: ETV6-NTRK3 gene fusions and trisomy 11 establish a histogenetic link between mesoblastic nephroma and congenital fibrosarcoma. Cancer Res 58: 5046-5048, 1998.

39. Sheng WQ,Hisaoka M,OkamotoS,TanakaA,Meis-Kindblom JM, Kindblom LG, Ishida T, Nojima T and Hashimoto H: Congenitalinfantile fibrosarcoma. A clinicopathologic study of 10 cases and molecular detection of the ETV6-NTRK3 fusion transcripts using paraffin-embedded tissues. Am J Clin Pathol 115: 348-355, 2001 .

40. Rubin BP, Chen CJ, Morgan TW, Xiao S, Grier HE, Kozakewich HP, Perez-Atayde AR and Fletcher JA: Congenital mesoblastic nephroma $\mathrm{t}(12 ; 15)$ is associated with ETV6-NTRK3 gene fusion: cytogenetic and molecular relationship to congenital (infantile) fibrosarcoma. Am J Pathol 153: 1451-1458, 1998.

41. Ramphal R, Manson D, Viero S, Zielenska M, Gerstle T and Pappo A: Retroperitoneal infantile fibrosarcoma: clinical, molecular, and therapeutic aspects of an unusual tumor. Pediatr Hematol Oncol 20: 635-642, 2003

42. Rizkalla H, Wildgrove H, Quinn F, Capra M and O'Sullivan MJ: Congenital fibrosarcoma of the ileum: case report with molecular confirmation and literature review. Fetal Pediatr Pathol 30: $156-160,2011$

43. Simon MP, Pedeutour F, Sirvent N, Grosgeorge J, Minoletti F, Coindre JM, Terrier-Lacombe MJ, Mandahl N, Craver RD, Blin N, Sozzi G, Turc-Carel C, O'Brien KP, Kedra D, Fransson I, Guilbaud C and Dumanski JP: Deregulation of the plateletderived growth factor B-chain gene via fusion with collagen gene COL1A1 in dermatofibrosarcoma protuberans and giant-cell fibroblastoma. Nat Genet 15: 95-98, 1997.

44. Navarro M, Simon MP, Migeon C, Turc-Carel C and Pedeutour F: COL1A1-PDGFB fusion in a ring chromosome 4 found in a dermatofibrosarcoma protuberans. Genes Chromosomes Cancer 23: 263-266, 1998.
45. Salgado R, Llombart B, M Pujol R, Fernández-Serra A, Sanmartín O, Toll A, Rubio L, Segura S, Barranco C, SerraGuillén C, Yébenes M, Salido M, Traves V, Monteagudo C, Sáez E, Hernández T, de Álava E, Llombart-Bosch A, Solé F, Guillén C, Espinet B and López-Guerrero JA: Molecular diagnosis of dermatofibrosarcoma protuberans: a comparison between reverse transcriptase-polymerase chain reaction and fluorescence in situ hybridization methodologies. Genes Chromosomes Cancer 50: 510-517, 2011

46. Segura S, Salgado R, Toll A, Martín-Ezquerra G, Yébenes M, Sáez A, Solé F, Barranco C, Umbert P, Espinet B and Pujol RM: Identification of $\mathrm{t}(17 ; 22)(\mathrm{q} 22 ; \mathrm{q} 13)$ (COL1A1/PDGFB) in dermatofibrosarcoma protuberans by fluorescence in situ hybridization in paraffin-embedded tissue microarrays. Hum Pathol 42: 176-184, 2011.

47. Walluks K, Chen Y, Woelfel C, Yang L, Cui T, Seliger C, Geier C, Knösel T, Hauke S and Petersen I: Molecular and clinicopathological analysis of dermatofibrosarcoma protuberans. Pathol Res Pract 209: 30-35, 2013.

48. O'Brien KP, Seroussi E, Dal Cin P, Sciot R, Mandahl N, Fletcher JA, Turc-Carel C and Dumanski JP: Various regions within the alpha-helical domain of the COL1A1 gene are fused to the second exon of the PDGFB gene in dermatofibrosarcomas and giant-cell fibroblastomas. Genes Chromosomes Cancer 23: 187-193, 1998 .

49. Macarenco RS, Zamolyi R, Franco MF, Nascimento AG, Abott JJ, Wang X, Erickson-Johnson MR and Oliveira AM: Genomic gains of COL1A1-PDFGB occur in the histologic evolution of giant cell fibroblastoma into dermatofibrosarcoma protuberans. Genes Chromosomes Cancer 47: 260-265, 2008.

50. Nishio J, Iwasaki H, Ohjimi Y, Ishiguro M, Isayama T, Naito M, Kaneko Y and Kikuchi M: Supernumerary ring chromosomes in dermatofibrosarcoma protuberans may contain sequences from 8q11.2-qter and 17q21-qter: a combined cytogenetic and comparative genomic hybridization study. Cancer Genet Cytogenet 129: 102-106, 2001.

51. Kaur S, Vauhkonen H, Böhling T, Mertens F, Mandahl N and Knuutila S: Gene copy number changes in dermatofibrosarcoma protuberans - a fine-resolution study using array comparative genomic hybridization. Cytogenet Genome Res 115: 283-288, 2006.

52. Wang J, Hisaoka M, Shimajiri S, Morimitsu $Y$ and Hashimoto H: Detection of COL1A1-PDGFB fusion transcripts in dermatofibrosarcoma protuberans by reverse transcription-polymerase chain reaction using archival formalin-fixed, paraffin-embedded tissues. Diagn Mol Pathol 8: 113-119, 1999.

53. Szollosi Z, Scholtz B, Egervari K and Nemes Z: Transformed dermatofibrosarcoma protuberans: real time polymerase chain reaction detection of COL1A1-PDGFB fusion transcripts in sarcomatous areas. J Clin Pathol 60: 190-194, 2007.

54. Craver R, Dewenter T, Ebran N and Pedeutour F: COL1A1-PDGFB fusion in a pediatric Bednar tumor with 2 copies of a der(22)t $(17 ; 22)$. Cancer Genet Cytogenet 168: 155-157, 2006.

55. Patel KU, Szabo SS, Hernandez VS, Prieto VG, Abruzzo LV, Lazar AJ and López-Terrada D: Dermatofibrosarcoma protuberans COL1A1-PDGFB fusion is identified in virtually all dermatofibrosarcoma protuberans cases when investigated by newly developed multiplex reverse transcription polymerase chain reaction and fluorescence in situ hybridization assays. Hum Pathol 39: 184-193, 2008.

56. Gibson S, Sebire NJ and Anderson J: Platelet-derived growth factor receptors and ligands are up-regulated in paediatric fibromatoses. Histopathology 51: 752-757, 2007.

57. Takahira T, Oda Y, Tamiya S, Higaki K, Yamamoto $H$, Kobayashi C, Izumi T, Tateishi N, Iwamoto Y and Tsuneyoshi M: Detection of COL1A1-PDGFB fusion transcripts and PDGFB/PDGFRB mRNA expression in dermatofibrosarcoma protuberans. Mod Pathol 20: 668-675, 2007.

58. Muchemwa FC, Wakasugi S, Honda Y and Ihn H: PDGFB quantification is a useful tool in the diagnosis of dermatofibrosarcoma protuberans: a study of 10 cases. Clin Exp Dermatol 35: 295-299, 2010.

59. Engel R, Ritterbach J, Schwabe D and Lampert F: Chromosome translocation $(2 ; 13)(\mathrm{q} 37 ; \mathrm{q} 14)$ in a disseminated alveolar rhabdomyosarcoma. Eur J Pediatr 148: 69-71, 1988.

60. Mehra S, de la Roza G, Tull J, Shrimpton A, Valente A and Zhang S: Detection of FOXO1 (FKHR) gene break-apart by fluorescence in situ hybridization in formalin-fixed, paraffinembedded alveolar rhabdomyosarcomas and its clinicopathologic correlation. Diagn Mol Pathol 17: 14-20, 2008. 
61. Liu J, Guzman MA, Pezanowski D, Patel D, Hauptman J, Keisling M, Hou SJ, Papenhausen PR, Pascasio JM, Punnett HH, Halligan GE and de Chadarévian JP: FOXO1-FGFR1 fusion and amplification in a solid variant of alveolar rhabdomyosarcoma. Mod Pathol 24: 1327-1335, 2011.

62. Biegel JA, Nycum LM, Valentine V, Barr FG and Shapiro DN: Detection of the $\mathrm{t}(2 ; 13)(\mathrm{q} 35 ; \mathrm{q} 14)$ and PAX3-FKHR fusion in alveolar rhabdomyosarcoma by fluorescence in situ hybridization. Genes Chromosomes Cancer 12: 186-192, 1995.

63. McManus AP, O'Reilly MA, Jones KP, Gusterson BA, Mitchell CD, Pinkerton CR and Shipley JM: Interphase fluorescence in situ hybridization detection of $\mathrm{t}(2 ; 13)(\mathrm{q} 35 ; \mathrm{q} 14)$ in alveolar rhabdomyosarcoma - a diagnostic tool in minimally invasive biopsies. J Pathol 178: 410-414, 1996

64. Matsumura T, Yamaguchi T, Seki K, Shimoda T, Wada T, Yamashita T and Hasegawa T: Advantage of FISH analysis using FKHR probes for an adjunct to diagnosis of rhabdomyosarcomas. Virchows Arch 452: 251-258, 2008.

65. Miura Y, Keira Y, Ogino J, Nakanishi K, Noguchi H, Inoue T and Hasegawa T: Detection of specific genetic abnormalities by fluorescence in situ hybridization in soft tissue tumors. Pathol Int 62: 16-27, 2012.

66. Barr FG, Chatten J, D'Cruz CM, Wilson AE, Nauta LE, Nycum LM, Biegel JA and Womer RB: Molecular assays for chromosomal translocations in the diagnosis of pediatric soft tissue sarcomas. JAMA 273: 553-557, 1995.

67. Arden KC, Anderson MJ, Finckenstein FG, Czekay S and Cavenee WK: Detection of the $\mathrm{t}(2 ; 13)$ chromosomal translocation in alveolar rhabdomyosarcoma using the reverse transcriptasepolymerase chain reaction. Genes Chromosomes Cancer 16: 254-260, 1996.

68. Kelly KM, Womer RB and Barr FG: Minimal disease detection in patients with alveolar rhabdomyosarcoma using a reverse transcriptase-polymerase chain reaction method. Cancer 78: $1320-1327,1996$

69. Sorensen PH, Lynch JC, Qualman SJ, Tirabosco R, Lim JF, Maurer HM, Bridge JA, Crist WM, Triche TJ and Barr FG: PAX3-FKHR and PAX7-FKHR gene fusions are prognostic indicators in alveolar rhabdomyosarcoma: a report from the children's oncology group. J Clin Oncol 20: 2672-2679, 2002.

70. Thway K, Rockcliffe S, Gonzalez D, Swansbury J, Min T, Thompson L and Fisher C: Utility of sarcoma-specific fusion gene analysis in paraffin-embedded material for routine diagnosis at a specialist centre. J Clin Pathol 63: 508-512, 2010.

71. Eguía-Aguilar P, Ponce-Castañeda V, Nájera-García N, Nieto-Martínez K, Kofman-Alfaro S, Sadowinski-Pine S, ValenciaMayoral P, Arenas-Huertero F and Perezpeña-Diazconti M: Detection of fusion genes in formalin-fixed paraffin-embedded tissue sections of rhabdomyosarcoma by RT-PCR and fluorescence in situ hybridization in Mexican patients. Arch Med Res 41: $119-124,2010$

72. Downing JR, Khandekar A, Shurtleff SA, Head DR, Parham DM, Webber BL, Pappo AS, Hulshof MG, Conn WP and Shapiro DN: Multiplex RT-PCR assay for the differential diagnosis of alveolar rhabdomyosarcoma and Ewing's sarcoma. Am J Pathol 146: 626-634, 1995

73. Anderson J, Renshaw J, McManus A, Carter R, Mitchell C Adams S and Pritchard-Jones K: Amplification of the $\mathrm{t}(2 ; 13)$ and $\mathrm{t}(1 ; 13)$ translocations of alveolar rhabdomyosarcoma in small formalin-fixed biopsies using a modified reverse transcriptase polymerase chain reaction. Am J Pathol 150: 477-482, 1997.

74. Athale UH, Shurtleff SA, Jenkins JJ, Poquette CA, Tan M, Downing JR and Pappo AS: Use of reverse transcriptase polymerase chain reaction for diagnosis and staging of alveolar rhabdomyosarcoma, Ewing sarcoma family of tumors, and desmoplastic small round cell tumor. J Pediatr Hematol Oncol 23: 99-104, 2001.

75. Edwards RH, Chatten J, Xiong QB and Barr FG: Detection of gene fusions in rhabdomyosarcoma by reverse transcriptasepolymerase chain reaction assay of archival samples. Diagn Mol Pathol 6: 91-97, 1997.

76. Chen BF, Chen ML, Liang DC, Huang YW, Liu HC and Chen SH: Detection of PAX3-FKHR and PAX7-FKHR fusion transcripts in rhabdomyosarcoma by reverse transcriptase-polymerase chain reaction using paraffin-embedded tissue. Zhonghua Yi Xue Za Zhi (Taipei) 62: 86-91, 1999

77. Jin L, Majerus J, Oliveira A, Inwards CY, Nascimento AG, Burgart LJ and Lloyd RV: Detection of fusion gene transcripts in fresh-frozen and formalin-fixed paraffin-embedded tissue sections of soft-tissue sarcomas after laser capture microdissection and rt-PCR. Diagn Mol Pathol 12: 224-230, 2003.
78. Fritsch MK, Bridge JA, Schuster AE, Perlman EJ and Argani P: Performance characteristics of a reverse transcriptase-polymerase chain reaction assay for the detection of tumor-specific fusion transcripts from archival tissue. Pediatr Dev Pathol 6: 43-53, 2003.

79. Peter M, Gilbert E and Delattre O: A multiplex real-time per assay for the detection of gene fusions observed in solid tumors. Lab Invest 81: 905-912, 2001

80. Krsková L, Mrhalová M, Hilská I, Sumerauer D, Drahokoupilová E, Múdry P and Kodet R: Detection and clinical significance of bone marrow involvement in patients with rhabdomyosarcoma. Virchows Arch 456: 463-472, 2010.

81. Hostein I, Andraud-Fregeville M, Guillou L, Terrier-Lacombe MJ, Deminière $\mathrm{C}$, Ranchère $\mathrm{D}$, Lussan $\mathrm{C}$, Longavenne $\mathrm{E}$, Bui NB, Delattre $\mathrm{O}$ and Coindre JM: Rhabdomyosarcoma: value of myogenin expression analysis and molecular testing in diagnosing the alveolar subtype: an analysis of 109 paraffinembedded specimens. Cancer 101: 2817-2824, 2004.

82. Turc-Carel C, Dal Cin P, Limon J, Rao U, Li FP, Corson JM, Zimmerman R, Parry DM, Cowan JM, Sandberg AA: Involvement of chromosome $\mathrm{X}$ in primary cytogenetic change in human neoplasia: nonrandom translocation in synovial sarcoma. Proc Natl Acad Sci USA 84: 1981-1985, 1987.

83. Clark J, Rocques PJ, Crew AJ, Gill S, Shipley J, Chan AM, Gusterson BA and Cooper CS: Identification of novel genes, SYT and SSX, involved in the $\mathrm{t}(\mathrm{X} ; 18)(\mathrm{p} 11.2 ; \mathrm{q} 11.2)$ translocation found in human synovial sarcoma. Nat Genet 7: 502-508, 1994.

84. de Leeuw B, Balemans M, Olde Weghuis D and Geurts van Kessel A: Identification of two alternative fusion genes, SYT-SSX1 and SYT-SSX2, in $\mathrm{t}(\mathrm{X} ; 18)(\mathrm{p} 11.2 ; \mathrm{q} 11.2)$-positive synovial sarcomas. Hum Mol Genet 4: 1097-1099, 1995.

85. Lee W, Han K, Harris CP, Shim S, Kim S and Meisner LF: Use of FISH to detect chromosomal translocations and deletions. Analysis of chromosome rearrangement in synovial sarcoma cells from paraffin-embedded specimens. Am J Pathol 143: $15-19,1993$

86. Knight JC, Reeves BR, Kearney L, Monaco AP, Lehrach H and Cooper CS: Localization of the synovial sarcoma $t(X ; 18)$ (p11.2;q11.2) breakpoint by fluorescence in situ hybridization. Hum Mol Genet 1: 633-637, 1992.

87. de Leeuw B, Suijkerbuijk RF, Balemans M, Sinke RJ, de Jong B, Molenaar WM, Meloni AM, Sandberg AA, Geraghty M and Hofker M: Sublocalization of the synovial sarcoma-associated $\mathrm{t}(\mathrm{X} ; 18)$ chromosomal breakpoint in Xp11.2 using cosmid cloning and fluorescence in situ hybridization. Oncogene 8: 1457-1463, 1993.

88. Motoi T, Kumagai A, Tsuji K, Imamura T and Fukusato T: Diagnostic utility of dual-color break-apart chromogenic in situ hybridization for the detection of rearranged SS18 in formalinfixed, paraffin-embedded synovial sarcoma. Hum Pathol 41: 1397-1404, 2010.

89. Terry J, Barry TS, Horsman DE, Hsu FD, Gown AM, Huntsman DG and Nielsen TO: Fluorescence in situ hybridization for the detection of $\mathrm{t}(\mathrm{X} ; 18)(\mathrm{p} 11.2 ; \mathrm{q} 11.2)$ in a synovial sarcoma tissue microarray using a breakapart-style probe. Diagn Mol Pathol 14: 77-82, 2005.

90. Geiersbach K, Rector LS, Sederberg M, Hooker A, Randall RL, Schiffman JD and South ST: Unknown partner for USP6 and unusual SS18 rearrangement detected by fluorescence in situ hybridization in a solid aneurysmal bone cyst. Cancer Genet 204: 195-202, 2011.

91. Kanemitsu S, Hisaoka M, Shimajiri S, Matsuyama A and Hashimoto H: Molecular detection of SS18-SSX fusion gene transcripts by cRNA in situ hybridization in synovial sarcoma using formalin-fixed, paraffin-embedded tumor tissue specimens. Diagn Mol Pathol 16: 9-17, 2007.

92. Argani P, Zakowski MF, Klimstra DS, Rosai J and Ladanyi M: Detection of the SYT-SSX chimeric RNA of synovial sarcoma in paraffin-embedded tissue and its application in problematic cases. Mod Pathol 11: 65-71, 1998.

93. Guillou L, Coindre J, Gallagher G, Terrier P, Gebhard S, de Saint Aubain Somerhausen N, Michels J, Jundt G, Vince DR, Collin F, Trassard M, Le Doussal V and Benhattar J: Detection of the synovial sarcoma translocation $\mathrm{t}(\mathrm{X} ; 18)$ (SYT;SSX) in paraffinembedded tissues using reverse transcriptase-polymerase chain reaction: a reliable and powerful diagnostic tool for pathologists. A molecular analysis of 221 mesenchymal tumors fixed in different fixatives. Hum Pathol 32: 105-112, 2001.

94. Fligman I, Lonardo F, Jhanwar SC, Gerald WL, Woodruff J and Ladanyi M: Molecular diagnosis of synovial sarcoma and characterization of a variant SYT-SSX2 fusion transcript. Am J Pathol 147: 1592-1599, 1995. 
95. Safar A, Wickert R, Nelson M, Neff JR and Bridge JA Characterization of a variant SYT-SSX1 synovial sarcoma fusion transcript. Diagn Mol Pathol 7: 283-287, 1998.

96. Tsuji S, Hisaoka M, Morimitsu Y, Hashimoto H, Shimajiri S Komiya S, Ushijima M and Nakamura T: Detection of SYT-SSX fusion transcripts in synovial sarcoma by reverse transcriptionpolymerase chain reaction using archival paraffin-embedded tissues. Am J Pathol 153: 1807-1812, 1998.

97. Sanders ME, van de Rijn M and Barr FG: Detection of a variant SYT-SSX1 fusion in a case of predominantly epithelioid synovial sarcoma. Mol Diagn 4: 65-70, 1999.

98. Katenkamp K, Richter P, Slatosch T, Katenkamp D and Berndt A: Simultaneous analysis of $\mathrm{t}(\mathrm{X} ; 18)$ by FISH- und SYT/SSX-RT-PCR in synovial sarcoma. Pathologe 26: 111-116, 2005 (In German).

99. Cummings TJ, Brown NM and Stenzel TT: TaqMan junction probes and the reverse transcriptase polymerase chain reaction detection of alveolar rhabdomyosarcoma, synovial sarcoma, and desmoplastic small round cell tumor. Ann Clin Lab Sci 32: 219-224, 2002.

100. Coindre JM,Hostein I, Benhattar J,Lussan C, Rivel J and Guillou L: Malignant peripheral nerve sheath tumors are $\mathrm{t}(\mathrm{X} ; 18)$-negative sarcomas. Molecular analysis of 25 cases occurring in neurofibromatosis type 1 patients, using two different RT-PCR-based methods of detection. Mod Pathol 15: 589-592, 2002

101. Hostein I, Menard A, Bui BN, Lussan C, Wafflart J, Delattre O, Peter M, Benhattar J, Guillou L and Coindre JM: Molecular detection of the synovial sarcoma translocation $t(X ; 18)$ by real-time polymerase chain reaction in paraffin-embedded material. Diagn Mol Pathol 11: 16-21, 2002.

102. Bijwaard KE, Fetsch JF, Przygodzki R, Taubenberger JK and Lichy JH: Detection of SYT-SSX fusion transcripts in archival synovial sarcomas by real-time reverse transcriptase-polymerase chain reaction. J Mol Diagn 4: 59-64, 2002.

103. Wang WL, Mayordomo E, Zhang W, Hernandez VS, Tuvin D, Garcia L, Lev DC, Lazar AJ and López-Terrada D: Detection and characterization of EWSR1/ATF1 and EWSR1/CREB1 chimeric transcripts in clear cell sarcoma (melanoma of soft parts). Mod Pathol 22: 1201-1209, 2009.

104.Hiraga H, Nojima T, Abe S, Yamashiro K, Yamawaki S, Kaneda K and Nagashima K: Establishment of a new continuous clear cell sarcoma cell line. Morphological and cytogenetic characterization and detection of chimaeric EWS/ATF-1 transcripts. Virchows Arch 431: 45-51, 1997.

105. Yamaguchi U, Hasegawa T, Morimoto Y, Tateishi U, Endo M, Nakatani F, Kawai A, Chuman H, Beppu Y, Endo M, Kurotaki H and Furuta K: A practical approach to the clinical diagnosis of Ewing's sarcoma/primitive neuroectodermal tumour and other small round cell tumours sharing EWS rearrangement using new fluorescence in situ hybridisation probes for EWSR1 on formalin fixed, paraffin wax embedded tissue. J Clin Pathol 58 1051-1056, 2005.

106. Song JS, Choi J, Kim JH, Jang SJ and Cho KJ: Diagnostic utility of EWS break-apart fluorescence in situ hybridization in distinguishing between non-cutaneous melanoma and clear cell sarcoma. Pathol Int 60: 608-613, 2010.

107.Patel RM, Downs-Kelly E, Weiss SW, Folpe AL, Tubbs RR, Tuthill RJ, Goldblum JR and Skacel M: Dual-color, break-apart fluorescence in situ hybridization for EWS gene rearrangement distinguishes clear cell sarcoma of soft tissue from malignant melanoma. Mod Pathol 18: 1585-1590, 2005.

108. Speleman F, Delattre O, Peter M, Hauben E, Van Roy N and Van Marck E: Malignant melanoma of the soft parts (clear-cell sarcoma): confirmation of EWS and ATF-1 gene fusion caused by a $\mathrm{t}(12 ; 22)$ translocation. Mod Pathol 10: 496-499, 1997.

109. Panagopoulos I, Mertens F, Dêbiec-Rychter M, Isaksson M, Limon J, Kardas I, Domanski HA, Sciot R, Perek D, Crnalic S, Larsson O and Mandahl N: Molecular genetic characterization of the EWS/ATF1 fusion gene in clear cell sarcoma of tendons and aponeuroses. Int J Cancer 99: 560-567, 2002.

110. Antonescu CR, Tschernyavsky SJ, Woodruff JM, Jungbluth AA, Brennan MF and Ladanyi M: Molecular diagnosis of clear cel sarcoma: detection of EWS-ATF1 and MITF-M transcripts and histopathological and ultrastructural analysis of 12 cases. J Mol Diagn 4: 44-52, 2002.

111. Coindre JM, Hostein I, Terrier P, Bouvier-Labit C, Collin F, Michels JJ, Trassard M, Marques B, Ranchere D and Guillou L: Diagnosis of clear cell sarcoma by real-time reverse transcriptasepolymerase chain reaction analysis of paraffin embedded tissues: clinicopathologic and molecular analysis of 44 patients from the French sarcoma group. Cancer 107: 1055-1064, 2006.
112. Ladanyi M and Gerald W: Fusion of the EWS and WT1 genes in the desmoplastic small round cell tumor. Cancer Res 54: 2837-2840, 1994.

113. Karnieli E, Werner H, Rauscher FJ III, Benjamin LE and LeRoith D: The IGF-I receptor gene promoter is a molecular target for the Ewing's sarcoma-Wilms' tumor 1 fusion protein. J Biol Chem 271: 19304-19309, 1996.

114. Benjamin LE, Fredericks WJ, Barr FG and Rauscher FJ III: Fusion of the EWS1 and WT1 genes as a result of the $t(11 ; 22)(p 13 ; q 12)$ translocation in desmoplastic small round cell tumors. Med Pediatr Oncol 27: 434-439, 1996.

115. Barnoud R, Delattre O, Péoc'h M, Pasquier D, Plantaz D, Leroux D and Pasquier B: Desmoplastic small round cell tumor: RT-PCR analysis and immunohistochemical detection of the Wilm's tumor gene WT1. Pathol Res Pract 194: 693-700, 1998.

116. Gerald WL, Rosai J and Ladanyi M: Characterization of the genomic breakpoint and chimeric transcripts in the EWS-WT1 gene fusion of desmoplastic small round cell tumor. Proc Natl Acad Sci USA 92: 1028-1032, 1995

117. Rauscher FJ III, Benjamin LE, Fredericks WJ and Morris JF: Novel oncogenic mutations in the WT1 Wilms' tumor suppressor gene: a $\mathrm{t}(11 ; 22)$ fuses the Ewing's sarcoma gene, EWS1, to WT1 in desmoplastic small round cell tumor. Cold Spring Harb Symp Quant Biol 59: 137-146, 1994.

118. Antonescu CR, Gerald WL, Magid MS and Ladanyi M Molecular variants of the EWS-WT1 gene fusion in desmoplastic small round cell tumor. Diagn Mol Pathol 7: 24-28, 1998.

119. Hill DA, Pfeifer JD, Marley EF, Dehner LP, Humphrey PA, Zhu X and Swanson PE: WT1 staining reliably differentiates desmoplastic small round cell tumor from Ewing sarcoma/ primitive neuroectodermal tumor. An immunohistochemical and molecular diagnostic study. Am J Clin Pathol 114: 345-353, 2000.

120. Brodie SG, Stocker SJ, Wardlaw JC, Duncan MH, McConnell TS, Feddersen RM and Williams TM: EWS and WT-1 gene fusion in desmoplastic small round cell tumor of the abdomen. Hum Pathol 26: 1370-1374, 1995.

121.Liu J, Nau MM, Yeh JC, Allegra CJ, Chu E and Wright JJ: Molecular heterogeneity and function of EWS-WT1 fusion transcripts in desmoplastic small round cell tumors. Clin Cancer Res 6: 3522-3529, 2000.

122. Su LD, Atayde-Perez A, Sheldon S, Fletcher JA and Weiss SW: Inflammatory myofibroblastic tumor: cytogenetic evidence supporting clonal origin. Mod Pathol 11: 364-368, 1998.

123. Souid AK, Ziemba MC, Dubansky AS, Mazur M, Oliphant M, Thomas FD, Ratner M and Sadowitz PD: Inflammatory myofibroblastic tumor in children. Cancer 72: 2042-2048, 1993.

124. Griffin CA, Hawkins AL, Dvorak C, Henkle C, Ellingham T and Perlman EJ: Recurrent involvement of 2p23 in inflammatory myofibroblastic tumors. Cancer Res 59: 2776-2780, 1999

125. Tan LH, Do E, Tan SY, Chong SM and Koay ES: Multi-lineage interrogation of the performance characteristics of a splitsignal fluorescence in situ hybridization probe for anaplastic lymphoma kinase gene rearrangements: a study of 101 cases characterized by immunohistomorphology on fixed archival tissue. Mol Diagn 8: 213-229, 2004.

126. Sirvent N, Hawkins AL, Moeglin D, Coindre JM, Kurzenne JY, Michiels JF, Barcelo G, Turc-Carel C, Griffin CA and Pedeutour F: ALK probe rearrangement in a $\mathrm{t}(2 ; 11 ; 2)(\mathrm{p} 23 ; \mathrm{p} 15 ; \mathrm{q} 31)$ translocation found in a prenatal myofibroblastic fibrous lesion: toward a molecular definition of an inflammatory myofibroblastic tumor family? Genes Chromosomes Cancer 31: 85-90, 2001.

127. Stoll LM and Li QK: Cytology of fine-needle aspiration of inflammatory myofibroblastic tumor. Diagn Cytopathol 39: 663-672, 2011

128. Borak S, Siegal GP, Reddy V, Jhala N and Jhala D: Metastatic inflammatory myofibroblastic tumor identified by EUS-FNA in mediastinal lymph nodes with ancillary FISH studies for ALK rearrangement. Diagn Cytopathol 40 (Suppl 2): S118-S125, 2012.

129. Li XQ, Hisaoka M, Shi DR, Zhu XZ and Hashimoto H: Expression of anaplastic lymphoma kinase in soft tissue tumors: an immunohistochemical and molecular study of 249 cases. Hum Pathol 35: 711-721, 2004.

130. Alaggio R, Barisani D, Ninfo V, Rosolen A and Coffin CM: Morphologic overlap between infantile myofibromatosis and infantile fibrosarcoma: A pitfall in diagnosis. Pediatr Dev Pathol 11: 355-362, 2008

131. Lawrence B, Perez-Atayde A, Hibbard MK, Rubin BP, Dal Cin P, Pinkus JL, Pinkus GS, Xiao S, Yi ES, Fletcher CD and Fletcher JA: TPM3-ALK and TPM4-ALK oncogenes in inflammatory myofibroblastic tumors. Am J Pathol 157: 377-384, 2000. 
132. Cools J, Wlodarska I, Somers R, Mentens N, Pedeutour F Maes B, De Wolf-Peeters C, Pauwels P, Hagemeijer A and Marynen P: Identification of novel fusion partners of ALK, the anaplastic lymphoma kinase, in anaplastic large-cell lymphoma and inflammatory myofibroblastic tumor. Genes Chromosomes Cancer 34: 354-362, 2002.

133. Lamant L, Dastugue N, Pulford K, Delsol G and Mariamé B: A new fusion gene TPM3-ALK in anaplastic large cell lymphoma created by a $(1 ; 2)(\mathrm{q} 25 ; \mathrm{p} 23)$ translocation. Blood 93: 3088-3095, 1999.

134.Drexler HG, Gignac SM, von Wasielewski R, Werner M and Dirks WG: Pathobiology of NPM-ALK and variant fusion genes in anaplastic large cell lymphoma and other lymphomas. Leukemia 14: 1533-1559, 2000.

135. Bridge JA, Kanamori M, Ma Z, Pickering D, Hill DA, Lydiatt W, Lui MY, Colleoni GW, Antonescu CR, Ladanyi M and Morris SW: Fusion of the ALK gene to the clathrin heavy chain gene, CLTC, in inflammatory myofibroblastic tumor. Am J Pathol 159: 411-415, 2001

136. Wang X, Krishnan C, Nguyen EP, Meyer KJ, Oliveira JL, Yang P, Yi ES, Erickson-Johnson MR, Yaszemski MJ, Maran A and Oliveira AM: Fusion of dynactin 1 to anaplastic lymphoma kinase in inflammatory myofibroblastic tumor. Hum Pathol 43 : 2047-2052, 2012.

137.Panagopoulos I, Nilsson T, Domanski HA, Isaksson M, Lindblom P, Mertens F and Mandahl N: Fusion of the SEC31L1 and ALK genes in an inflammatory myofibroblastic tumor. Int J Cancer 118: 1181-1186, 2006.

138. Butrynski JE, D'Adamo DR, Hornick JL, Dal Cin P, Antonescu CR, Jhanwar SC, Ladanyi M, Capelletti M, Rodig SJ, Ramaiya N, Kwak EL, Clark JW, Wilner KD, Christensen JG, Jänne PA, Maki RG, Demetri GD and Shapiro GI: Crizotinib in ALK-rearranged inflammatory myofibroblastic tumor. N Engl J Med 363: 1727-1733, 2010.

139. Tothova Z and Wagner AJ: Anaplastic lymphoma kinasedirected therapy in inflammatory myofibroblastic tumors. Curr Opin Oncol 24: 409-413, 2012

140.Lieberman PH, Brennan MF, Kimmel M, Erlandson RA, Garin-Chesa P and Flehinger BY: Alveolar soft-part sarcoma A clinico-pathologic study of half a century. Cancer 63: 1-13, 1989.

141. Ordonez NG: Alveolar soft part sarcoma: a review and update. Adv Anat Pathol 6: 125-139, 1999.

142. Joyama S, Ueda T, Shimizu K, Kudawara I, Mano M, Funai H, Takemura K and Yoshikawa H: Chromosome rearrangement at 17q25 and xp11.2 in alveolar soft-part sarcoma: A case report and review of the literature. Cancer 86: 1246-1250, 1999

143. Uppal S, Aviv H, Patterson F, Cohen S, Benevenia J, Aisner S and Hameed M: Alveolar soft part sarcoma - reciprocal translocation between chromosome 17q25 and Xp11. Report of a case with metastases at presentation and review of the literature. Acta Orthop Belg 69: 182-187, 2003

144. Amin MB, Patel RM, Oliveira P, Cabrera R, Carneiro V, Preto M, Balzer B and Folpe AL: Alveolar soft-part sarcoma of the urinary bladder with urethral recurrence: a unique case with emphasis on differential diagnoses and diagnostic utility of an immunohistochemical panel including TFE3. Am J Surg Pathol 30: 1322-1325, 2006

145. Heimann P, Devalck C, Debusscher C, Sariban E and Vamos E: Alveolar soft-part sarcoma: further evidence by FISH for the involvement of chromosome band 17q25. Genes Chromosomes Cancer 23: 194-197, 1998.

146. Ladanyi M, Lui MY, Antonescu CR, Krause-Boehm A, Meindl A, Argani P, Healey JH, Ueda T, Yoshikawa $\mathrm{H}$, Meloni-Ehrig A, Sorensen PH, Merten s F, Mandahl N, van den Berghe H, Sciot R, Dal Cin P and Bridge J: The der(17) $\mathrm{t}(\mathrm{X} ; 17)(\mathrm{p} 11 ; \mathrm{q} 25)$ of human alveolar soft part sarcoma fuses the TFE3 transcription factor gene to ASPL, a novel gene at 17q25. Oncogene 20: 48-57, 2001.

147. Argani P, Antonescu CR, Illei PB, Lui MY, Timmons CF, Newbury R, Reuter VE, Garvin AJ, Perez-Atayde AR, Fletcher JA, Beckwith JB, Bridge JA and Ladanyi M: Primary renal neoplasms with the ASPL-TFE3 gene fusion of alveolar soft part sarcoma: a distinctive tumor entity previously included among renal cell carcinomas of children and adolescents. Am J Pathol 159: 179-192, 2001.

148. Aulmann S, Longerich T, Schirmacher P, Mechtersheimer G and Penzel R: Detection of the ASPSCR1-TFE3 gene fusion in paraffin-embedded alveolar soft part sarcomas. Histopathology 50: 881-886, 2007.
149. Hoshino M, Ogose A, Kawashima H, Izumi T, Hotta T, Hatano H, Morita T, Otsuka H, Umezu H, Yanoma S, Tsukuda M and Endo N: Molecular analyses of cell origin and detection of circulating tumor cells in the peripheral blood in alveolar soft part sarcoma. Cancer Genet Cytogenet 190: 75-80, 2009.

150. Pink D, Bertz-Lepel J, Busemann C, Bitz U and Reichardt P: Efficacy of trabectedin in patients with advanced or metastatic alveolar soft-part sarcoma. Onkologie 35: 249-252, 2012.

151.Tsuneyoshi M, Enjoji M, Iwasaki $\mathrm{H}$ and Shinohara N: Extraskeletal myxoid chondrosarcoma - a clinicopathologic and electron microscopic study. Acta Pathol Jpn 31: 439-447, 1981

152. Saleh G, Evans HL, Ro JY and Ayala AG: Extraskeletal myxoid chondrosarcoma. A clinicopathologic study of ten patients with long-term follow-up. Cancer 70: 2827-2830, 1992.

153. Gebhardt MC, Parekh SG, Rosenberg AE and Rosenthal DI: Extraskeletal myxoid chondrosarcoma of the knee. Skeletal Radiol 28: 354-358, 1999.

154. Meis-Kindblom JM, Bergh P, Gunterberg B and Kindblom LG: Extraskeletal myxoid chondrosarcoma: a reappraisal of its morphologic spectrum and prognostic factors based on 117 cases. Am J Surg Pathol 23: 636-650, 1999.

155. Sciot R, Dal Cin P, Fletcher C, Samson I, Smith M, De Vos R, Van Damme B and Van den Berghe H: $\mathrm{t}(9 ; 22)(\mathrm{q} 22-31 ; \mathrm{q} 11-12)$ is a consistent marker of extraskeletal myxoid chondrosarcoma: evaluation of three cases. Mod Pathol 8: 765-768, 1995.

156. Rao UN, Surti U, Hoffner L, Howard T, Leger W, Contis L and Yaw K: Extraskeletal and skeletal myxoid chondrosarcoma: A multiparameter analysis of three cases including cytogenetic analysis and fluorescence in situ hybridization. Mol Diagn 1: 99-107, 1996.

157. Harris M, Coyne J, Tariq M, Eyden BP, Atkinson M, Freemont AJ, Varley J, Attwooll C and Telford N: Extraskeletal myxoid chondrosarcoma with neuroendocrine differentiation: a pathologic, cytogenetic, and molecular study of a case with a novel translocation $\mathrm{t}(9 ; 17)(\mathrm{q} 22 ; \mathrm{q} 11.2)$. Am J Surg Pathol 24: 1020-1026, 2000

158. Sjögren H, Wedell B, Meis-Kindblom JM, Kindblom LG and Stenman G: Fusion of the NH2-terminal domain of the basic helix-loop-helix protein TCF12 to TEC in extraskeletal myxoid chondrosarcoma with translocation $\mathrm{t}(9 ; 15)(\mathrm{q} 22 ; \mathrm{q} 21)$. Cancer Res 60: 6832-6835, 2000

159. Gan TI, Rowen L, Nesbitt R, Roe BA, Wu H, Hu P, Yao Z, Kim UJ, O'Sickey $\mathrm{T}$ and Bina M: Genomic organization of human TCF12 gene and spliced mRNA variants producing isoforms of transcription factor HTF4. Cytogenet Genome Res 98: 245-248, 2002.

160. Attwooll C, Tariq M, Harris M, Coyne JD, Telford N and Varley JM: Identification of a novel fusion gene involving hTAFII68 and CHN from a $\mathrm{t}(9 ; 17)(\mathrm{q} 22 ; \mathrm{q} 11.2)$ translocation in an extraskeletal myxoid chondrosarcoma. Oncogene 18: 7599-7601, 1999.

161. Lim B, Jun HJ, Kim AY, Kim S, Choi J, Kim J, et al: The TFG-TEC fusion gene created by the $\mathrm{t}(3 ; 9)$ translocation in human extraskeletal myxoid chondrosarcomas encodes a more potent transcriptional activator than TEC. Carcinogenesis 33: 1450-1458, 2012.

162. Brody RI, Ueda T, Hamelin A, Jhanwar SC, Bridge JA, Healey JH, Huvos AG, Gerald WL and Ladanyi M: Molecular analysis of the fusion of EWS to an orphan nuclear receptor gene in extraskeletal myxoid chondrosarcoma. Am J Pathol 150: 1049-1058, 1997.

163. Panagopoulos I, Mertens F, Isaksson M, Domanski HA, Brosjö O, Heim S, Bjerkehagen B, Sciot R, Dal Cin P, Fletcher JA, Fletcher CD and Mandahl N: Molecular genetic characterization of the EWS/CHN and RBP56/CHN fusion genes in extraskeletal myxoid chondrosarcoma. Genes Chromosomes Cancer 35: 340-352, 2002.

164. Jakowski JD and Wakely PE Jr: Cytopathology of extraskeletal myxoid chondrosarcoma: report of 8 cases. Cancer 111: 298-305, 2007.

165. Wang WL, Mayordomo E, Czerniak BA, Abruzzo LV, Dal Cin P, Araujo DM, Lev DC, López-Terrada D and Lazar AJ: Fluorescence in situ hybridization is a useful ancillary diagnostic tool for extraskeletal myxoid chondrosarcoma. Mod Pathol 21: 1303-1310, 2008.

166. Noguchi H, Mitsuhashi T, Seki K, Tochigi N, Tsuji M, Shimoda T and Hasegawa T: Fluorescence in situ hybridization analysis of extraskeletal myxoid chondrosarcomas using EWSR1 and NR4A3 probes. Hum Pathol 41: 336-342, 2010. 
167. Sjögren H, Meis-Kindblom JM, Orndal C, Bergh P, Ptaszynski K, Aman P, Kindblom LG and Stenman G: Studies on the molecular pathogenesis of extraskeletal myxoid chondrosarcoma-cytogenetic, molecular genetic, and cDNA microarray analyses. Am J Pathol 162: 781-792, 2003

168. Okamoto S, Hisaoka M, Ishida T, Imamura T, Kanda H, Shimajiri $\mathrm{S}$ and Hashimoto $\mathrm{H}$ : Extraskeletal myxoid chondrosarcoma: a clinicopathologic, immunohistochemical, and molecular analysis of 18 cases. Hum Pathol 32: 1116-1124, 2001.

169. Matsukuma S, Hisaoka M, Obara K, Kono T, Takeo H, Sato K and Hata Y: Primary pulmonary myxoid sarcoma with EWSR1-CREB1 fusion, resembling extraskeletal myxoid chondrosarcoma: Case report with a review of Literature. Pathol Int 62: 817-822, 2012.

170. Aurias A, Rimbaut C, Buffe D, Zucker JM and Mazabraud A: Translocation involving chromosome 22 in Ewing's sarcoma. A cytogenetic study of four fresh tumors. Cancer Genet Cytogenet 12: 21-25, 1984 .

171. Whang-Peng J, Triche TJ, Knutsen T, Miser J, Kao-Shan S, Tsai S and Israel MA: Cytogenetic characterization of selected small round cell tumors of childhood. Cancer Genet Cytogenet 21 185-208, 1986.

172. Burchill SA: Ewing's sarcoma: diagnostic, prognostic, and therapeutic implications of molecular abnormalities. J Clin Pathol 56: 96-102, 2003.

173. Gamberi G, Cocchi S, Benini S, Magagnoli G, Morandi L, Kreshak J, Gambarotti M, Picci P, Zanella L and Alberghini M: Molecular diagnosis in Ewing family tumors: the Rizzoli experience-222 consecutive cases in four years. J Mol Diagn 13: 313-324, 2011.

174. Kojima T, Asami S, Chin M, Yoshida Y, Mugishima H and Suzuki T: Detection of chimeric genes in Ewing's sarcoma and its clinical applications. Biol Pharm Bull 25: 991-994, 2002.

175. Davison JM, Morgan TW, Hsi BL, Xiao S and Fletcher JA: Subtracted, unique-sequence, in situ hybridization: experimental and diagnostic applications. Am J Pathol 153: 1401-1409, 1998.

176. Cantile M, Marra L, Franco R, Ascierto P, Liguori G, De Chiara A and Botti G: Molecular detection and targeting of EWSR1 fusion transcripts in soft tissue tumors. Med Oncol 30: 412, 2013.

177. Kumar S, Pack S, Kumar D, Walker R, Quezado M, Zhuang Z, Meltzer P and Tsokos M: Detection of EWS-FLI-1 fusion in Ewing's sarcoma/peripheral primitive neuroectodermal tumor by fluorescence in situ hybridization using formalin-fixed paraffin-embedded tissue. Hum Pathol 30: 324-330, 1999.

178. Hattinger CM, Rumpler S, Kovar H and Ambros PF: Finemapping of cytogenetically undetectable EWS/ERG fusions on DNA fibers of Ewing tumors. Cytogenet Cell Genet 93: 29-35, 2001

179. Newby R, Rowe D, Paterson L, Farquharson MA, MacDuff E, Coupe A, Hale J, Dildey P and Bown N: Cryptic EWSR1-FLI1 fusions in Ewing sarcoma: potential pitfalls in the diagnostic use of fluorescence in situ hybridization probes. Cancer Genet Cytogenet 200: 60-64, 2010

180. Mangham DC, Williams A, McMullan DJ, McClure J, Sumathi VP, Grimer RJ and Davies AM: Ewing's sarcoma of bone: the detection of specific transcripts in a large, consecutive series of formalin-fixed, decalcified, paraffin-embedded tissue samples using the reverse transcriptase-polymerase chain reaction. Histopathology 48: 363-376, 2006.
181. Park YK, Chi SG, Park HR, Yang MH and Unni KK: Detection of $\mathrm{t}(11 ; 22)(\mathrm{q} 24 ; \mathrm{q} 12)$ translocation of Ewing's sarcoma in paraffin embedded tissue by nested reverse transcription-polymerase chain reaction. J Korean Med Sci 13: 395-399, 1998.

182. Stegmaier S, Leuschner I, Aakcha-Rudel E, Münch P, Kazanowska B, Bekassy A, Treuner J and Koscielniak E: Identification of various exon combinations of the ews/fli1 translocation: an optimized RT-PCR method for paraffin embedded tissue - a report by the CWS-study group. Klin Padiatr 216: 315-322, 2004

183. Hisaoka M, Tsuji S, Morimitsu Y, Hashimoto H, Shimajiri S, Komiya S and Ushijima M: Molecular detection of EWS-FLI1 chimeric transcripts in Ewing family tumors by nested reverse transcription-polymerase chain reaction: application to archival paraffin-embedded tumor tissues. APMIS 107: 577-584, 1999.

184. Montanaro L, Pession A, Trerè D, Vici M, Prete A, Paolucci G and Derenzini M: Detection of EWS chimeric transcripts by nested RT-PCR to allow reinfusion of uncontaminated peripheral blood stem cells in high-risk Ewing's tumor in childhood. Haematologica 84: 1012-1015, 1999.

185. Yang Y, Zhang L, Wei Y, Wang H, Xiong W, Chen Z, Hes O and Zheng J: Detection of EWSR1 translocation with nuclear extraction-based fluorescence in situ hybridization for diagnosis of Ewing's sarcoma/primitive neuroectodermal tumor. Anal Quant Cytol Histol 29: 221-230, 2007.

186. Meier VS, Kühne T, Jundt G and Gudat F: Molecular diagnosis of Ewing tumors: improved detection of EWS-FLI-1 and EWS-ERG chimeric transcripts and rapid determination of exon combinations. Diagn Mol Pathol 7: 29-35, 1998

187. Wang M, Nilsson G, Carlberg M, Dricu A, Wejde J, Kreicbergs A and Larsson O: Specific and sensitive detection of the EWS/FLI1 fusion protein in Ewing's sarcoma by western blotting. Virchows Arch 432: 131-134, 1998.

188. Silva DS, Sawitzki FR, De Toni EC, Graebin P, Picanco JB, Abujamra AL, de Farias CB, Roesler R, Brunetto AL and Alho CS: Ewing's sarcoma: analysis of single nucleotide polymorphism in the EWS gene. Gene 509: 263-266, 2012.

189. Lewis TB, Coffin CM and Bernard PS: Differentiating Ewing's sarcoma from other round blue cell tumors using a RT-PCR translocation panel on formalin-fixed paraffin-embedded tissues. Mod Pathol 20: 397-404, 2007.

190. Angervall L and Kindblom LG: Principles for pathologicanatomic diagnosis and classification of soft-tissue sarcomas. Clin Orthop Relat Res 289: 9-18, 1993

191. Sreekantaiah C, Ladanyi M, Rodriguez E and Chaganti RS Chromosomal aberrations in soft tissue tumors. Relevance to diagnosis, classification, and molecular mechanisms. Am J Pathol 144: 1121-1134, 1994.

192. Ladanyi M and Bridge JA: Contribution of molecular genetic data to the classification of sarcomas. Hum Pathol 31: 532-538, 2000.

193. Bridge JA and Sandberg AA: Cytogenetic and molecular genetic techniques as adjunctive approaches in the diagnosis of bone and soft tissue tumors. Skeletal Radiol 29: 249-258, 2000.

194. Singer S: New diagnostic modalities in soft tissue sarcoma. Semin Surg Oncol 17: 11-22, 1999. 